\title{
A Special Aspect of Relevance: Countering Negative InfERENCES Associated WITH THE ABsence OF EVIDENCE
}

\author{
Stephen A. Saltzburg†
}

The American evidence system requires judges in every case in which an objection to offered evidence is raised to determine whether the evidence is relevant to the issues of the case and, if relevant, whether it is preferable to admit the evidence in order to recognize its probative force or to exclude it in furtherance of some other policy. Despite the complexity of this determination, judges often limit their examination of the probative value of evidence to the particular piece of evidence itself. Yet evidence will have or lack probative value not only of its own force, but also because of its relationship to other evidence in the case. In some fact situations, a jury will expect one side or the other to present certain evidence. If the evidence is not presented, the jury may conclude that the party cannot produce it when in fact the evidence is excluded for entirely different reasons. In short, the absence of certam evidence can be as significant a source of jurors' inferences as its admission.

This Article explores the significance of what I will call negative inferences: the inferences drawn by factfinders from the absence of one or more pieces of evidence that they expect to be presented. The analysis concentrates on two areas. The first is the basic case-by-case relevance analysis, beginning with the decision whether evidence is relevant and proceeding to the balancing test, required by evidentiary rules similar to Federal Rule of Evidence 403, that weighs the probative value of a particular piece of evidence agamst its prejudicial quality. This area involves a case-by-case analysis by the adjudicator to determine which evidence is relevant and which is inadmissible though relevant. I will argue that judges commonly fail to take a sufficiently broad view in weighing the probative value of evidence and that they should consider not only the positive effect of admitting a particular

$\dagger$ Professor of Law, Univcrsity of Virginia Law School. A.B. 1967, Dickinson College; J.D. 1970, University of Pennsylvania. 
piece of evidence, but also the negative effect, broadly viewed, of its exclusion. Once judges conclude that the probative force of an item of evidence may be substantially outweighed by its prejudicial effect, they should analyze the inferences a jury could draw from the absence of the evidence to strike an appropriate balance and select the fairest evidentiary package to present to the jury. My argument will be that it is nost important for the trial judge to focus on negative inferences, but that appellate courts can also benefit from the analysis herein suggested as long as they are aware of some pitfalls inherent in appellate review of evidentiary rulings. The second area of inquiry is evidentiary rulemaking. There are classes of cases presenting generahized fact patterns in which jurors will expect certain evidence to be introduced. For example, a plaintiff claiming a back injury will be expected to report pain or discounfort when exerting back muscles. Just as trial judges inust be sensitive to juror expectations in individual cases, rule drafters should try to assure that the rules that govern the admission of evidence in frequently arising cases reflect jurors' common expectations. The Article exammes some exceptions to the hearsay doctrine that may be understood better in light of the negative imference concept. After the section on liearsay some additional rules are explored. My analysis of negative inferences supports some of the present rules of evidence that have been criticized elsewhere and challenges certain other established or proposed rules.

A reexamination of fundamental principles of relevance and exclusion is an appropriate subject for an issue devoted to David Louisell, one of the most distinguished scliolars of procedure and evidence to teacl in an American law school in the last quarter century. ${ }^{1}$ Professor Louisell recognized the contmuing perplexity of relevance problems and their significance. ${ }^{2} \mathrm{He}$ demonstrated a commitment to rethink ideas too easily accepted as settled and to consider new justifications

1. Not only did he coauthor a bestselling evidence casebook, D. LoulSELL, J. KAPLAN \& J. WALTZ, CASES AND MATERIALS ON EVIDENCE (3d ed. 1976), but also a casebook in civil procedure, D. Louisell \& G. Hazard, Cases and Materials on Pleading and Procedure (3d ed. 1973), that contains some of the finest original notes available.

2. Perhaps it was in recognition of the difficulty and importance of understanding relevance that Professor Louisell and Professor Mueller devoted 246 pages of the first volume of their treatise on federal evidence to just two federal evidence rules-401 and 402 . 1 D. Louisel \& C. Mueller, Federal Evidence 635-880 (1977). Although Professor Louisell praiscd the Federal Rules of Evidence as a "major achievement of rationahity and systematization," he also reınarked, in a comment that probably reflected his view on evidence law generally, that:

[O]nly a pretender would claim for the Rules that now "All is for the best in a best of all possible worlds." There are deficiencies, mistakes and disappoimtment. Some are tangible, definite and certain; . . . there is no mistaking them. Others are unore clouded, speculative and subjective; these involve value judginents still reasonably debatable by reasonable men.

Id. at iii-iv. 
for old rules. ${ }^{3}$ And, as he realized, understanding a concept such as relevance requires constant reevaluation of the basics, for understanding can only be pursued, never achieved. I respectfully dedicate this Article to David Louisell and his teaching that true theory "means going to the bottom of the subject." 4

\section{The Significance of Negative Inferences}

\section{A. Background: Basic Rules of Admission and Exclusion}

This Article advocates neither a general contraction nor a general expansion of exclusionary rules of evidence. Rather, in dealing with particular cases, it accepts existing evidentiary rules and the traditional role of the trial judge in determining what is probative and admissible, what is probative but excluded, and what is irrelevant and never admissible. The Article accepts the view that rulings on the admissibility of evidence must focus on the costs as well as the benefits of admitting evidence and that the same is true when exclusion is contemplated. The costs of admission are, in fact, the benefits of exclusion and vice versa. All ad hoc rulings and all evidence rules recognize this; it is fundamental to what follows. As the Article develops, it scrutinizes the theory of admitting or excluding evidence set forth in a case or in a rule by carefully analyzing some hidden costs of exclusion. There is no preconceived notion of how inuch evidence optimially should be deeined admissible; each case or rule is considered on its own inerits. In short, familiar relevance and other evidence rules are discussed throughout-no new general rule is proposed. Rather, the Article develops a more sophisticated way of thinking about familiar problems of probative value and prejudicial effect.

If trials are to be conducted fairly, only relevant evidence can be admissible. This is one of the basic tenets of the American evidence system. ${ }^{5}$ While adjudication is not entirely a process of logical analysis, devoid of emotional response, the normative inodel of the evidence systein aims for rationahity. Most American courts instruct the jury to decide a case on "the evidence received in this trial and the law as stated to you by the court," and "not [to] be governed by inere sentiment,

3. See, eg., Louisell, Confidentiality, Conformity and Confusion: Privileges in Federal Court Today, 31 Tulane L. Rev. 101 (1956).

4. 1 D. Louisell \& C. MuEller, supra note 2, at iii (quoting Holmes, The Path of the Law, 10 HARv. L. REv. 457, 477 (1897)).

5. Thayer's oft-quoted lines underscore the fundamentality of the proposition:

There is a principle-not so much a rule of evidence as a presupposition involved in the very conception of a rational system of evidence, as contrasted with the old formal and mechanical systems-which forbids receiving anything irrelevant, not logically probative.

J. Thayer, A Preliminary Treatise on Evidence at the Common Law 264 (1898). 
conjecture, sympathy, passion, prejudice, public opmion or public feelings."

To be relevant, evidence must have some "tendency to make the existence of any fact that is of consequence to the determination of the action more probable or less probable than it would be without the evidence."7 Not only must the evidence relate to some matter disputed by the litigants, ${ }^{8}$ but the evidence must also assist the trier of fact in resolving disputed matters.

Once a judge determines that evidence is relevant, a second, equally fundamental principle is triggered: "[E]verything which is thus probative should come in, unless a clear ground of policy or law excludes it." The exclusion of relevant evidence is unacceptable unless

6. CALJIC No. 100 (3d ed. 1970). Some objections have been raised to undue emphasis on logic. See, e.g., Advisory Committee's Note to FED. R. Evid. 401, 56 F.R.D. 183, 215-16 (1973). Whether one prefers a "logical" or a "rational" decision, the goal sought is probably the same.

7. FED. R. Evid. 401. Irrelevant evidence is excluded by rules like FED. R. Evid. 402, whether or not a convincing showing can be made in any individual case that the evidence is harmful, for several reasons: First, by defimition the evidence cannot be helpful in logically disposing of the case. An assumption is made that generally it is less costly to take the time to entertain an objection and to exclude the irrelevant evidence than it is to present the evidence, to allow cross-examination and perhaps counter-evidence, and to have argument to the jury about its relevance. Second, the costs to the judicial systein might be increased dramatically were irrelevant evidence presumed to be admissible absent a showing of prejudice on the theory that the time needed to rule on pure relevance objections exceeds the time required to adnit and put into proper perspective irrelevant evidence. At trial few lawyers would content themselves with simple relevance objections. Factors such as prejudice and confusion would be argued in connection with every relevance poimt, thereby increasing the costs of hitigation. And it might prove more costly to force parties to argue on appeal about the harm associated with rulings rather than to allow them to make a more direct, simple relevance argument. Third, in jury cases there is soine danger that jurors might assume that improper evidence would not be allowed to come before them, a reasonable assumption in hight of the objections they hear made in court and the feeling they may get that the judge protects them by excluding all evidence they are not permitted to receive. Jurors inay attach weight to evidence that, logically at least, has no probative force. Fourth, the mintroduction of some irrelevant evidence would mevitably lead to criticisun that rulings admitting the irrelevant evidence for some people but not others are politically based, casting doubt on the integrity of the system. Finally, opening the door to evidence that does not fit the model of reason and logic would force a restatement of our conception of our systeln of evidence; Thayer's notion "of a rational system of evidence" is not the only notion possible, but alternatives might be unpalatable to most Americans.

8. Some tine ago Professor Morgan explained the practical operation of this aspect of the relevance requirement:

At present, in most jurisdictions, the pleadings alone will not suffice, for often they are arbitrarily cut off before an issue is made. What is provable depends, secondly, upon the pertinent rules of substantive law. Consequently, in order to determine what items of evidence are relevant, one must know both the issues and the applicable rules of substantive law.

E. Morgan, Basic Problems of State and Federal Evidence 168 (5th ed. 1976). This aspect of relevance is often referred to as "inateriality." See R. LEMPERT \& S. SALTZBURG, A MODERN APPROACH TO EVIDENCE 141-42 (1977). That term was rejected by the drafters of the federal rule on the ground that its many meanings might cause confusion, but the sane idea is carried forward in the words "fact that is of consequence to the dctermination of the action." FED. R. EvID. 401.

9. J. THAYER, supra note 5, at 530. This Article assumes that all legal rules of exclusion are grounded in pohicy and that exclusion on "policy" grounds is improper unless some accepted legal 
some policy against inclusion outweighs the probative value of the evidence offered. Indeed, irrational exclusion of evidence may harm a rational decisionmaking process more than irrational admission of evidence. Exclusion, on the one hand, absolutely deprives a party of proof when the excluded evidence is irreplaceable. According to the normative model, on the other hand, a trier of fact following the court's instructions will disregard irrelevant evidence. Thus, erroneous exclusion is final, but erroneous admission could be corrected by the jury.

Evidence is excluded to serve several judicial as well as nonjudi$\mathrm{cial}^{10}$ interests. An important judicial interest is to promote decisionmaking accuracy by admitting only evidence that ineets established standards of reliability. ${ }^{11}$ One of the most familiar rules based on this policy is the balancing test codified in Federal Rule of Evidence 403. Rule 403 provides:

Although relevant, evidence may be excluded if its probative value

rule directs the trial court to consider policy on an ad toc basis in ruling on the admissibility of evidence. For example, FED. R. EvID. 609(a)(1) sets forth a balancing test that is intended to protect criminal defendants who testify froin being unduly prejudiced as a result of impeachment by prior convictions. Obviously, the policies outlined in the rule can and inust be served by trial judges. But in some jurisdictions a balancing test for prior conviction impeachment evidence is explicitly or implicitly prohibited. Indeed, FED. R. EvID. 609(a)(I) itself has been read by some courts as implicitly providing no balancing protection for the government. See, e.g., United States v. Nevitt, 563 F.2d 406 (5th Cir. 1977); United States v. Martin, 562 F.2d 673, 680-81 n.16 (D.C. Cir. 1977). The latter opinion is somewlat surprising in hight of the following language in a case decided only shortly before Nevitt: "The Evidence Code does not attempt to write a catalog of all the rules whicl govern evidence that can be used to impeach a witness." United States v. AlvarezLopez, 559 F.2d 1155, 1158 (9th Cir. 1977). See also S. Saltzburg \& K. Redden, Federal RULES OF EVIDENCE MANUAL 331-32 (2d ed. 1977). If the rule is intended to prohibit balancing to protect the government or balancing in civil cases, trial judges are not entitled to disregard the prohibition and decide cases on the basis of policy, even if the policy was recognized as valid by the principal authorities used as a basis for drafting the federal rule. In fact, pre-rules cases had adopted a policy of protecting the government against unfair impeachment of its witnesses. See, e.g., Davis v. United States, 409 F.2d 453 (D.C. Cir. 1969) (developing the analysis of Luck v. United States, 348 F.2d 763 (D.C. Cir. 1965), virtually the only case cited by the Advisory Committee on Proposed Rules im the fornal legislative history of Rule 609(a)(1), 28 U.S.C.A. 287 (1975)). For a view that is admittedly restrictive and a most apologetic judicial opinion, see State v. Ruzicka, 89 Wash. 2d 217, 570 P.2d 1208 (1977).

10. For example, evidence is excluded to provide disincentives for public officials to engage in unconstitutional or otherwise illegal conduct, encourage socially desirable belıavior, preserve individual privacy and autonomy, protect confidential relationships, assure the security of the community and the personal safety of its members, recognize the importance of imterpersonal relationships, insulate public officials from the burdens of testifying, preserve the appearance of an unbiased tribunal, and foster federal-state relations.

11. Best evidence rules, for example, are intended to proinote accuracy and to protect against fraud. See generally Rogers, The Best Evidence Rule, 1945 WIS. L. Rev. 278. Special authentication requirements, whether deemed substantive or evidentiary, rest in part on a belief in their capacity to assure an accurate reconstruction of low an event oceurred. See C. McCorMICK, HANDBOOK OF THE LAW OF EvidENCE 545-47 (2d ed. E. Cleary 1972). Rules that establish criteria for expert witness testimony, see, e.g., FED. R. EvID. 702 and the last sentence of FED. R. EVD. 703, manifest the view that minimunı standards are necessary if reliability of verdicts is to be enhanced. Restrictions on the use of scientific evidence reflect a similar view. See generally Strong, Questions Affecting the Admissibility of Scientific Evidence, 1970 U. ILL. L.F. 1, 10-15. 
is substantially outweighed by the danger of unfair prejudice, confusion of the issues, or misleading the jury, or by considerations of undue delay, waste of time, or needless presentation of cuinulative evidence. ${ }^{12}$ Once trial judges decide in response to objections that evidence is relevant, they almost always must decide whether the costs of admitting the evidence-increasing the length of trial, the parties' out-of-pocket expenses, the external costs of delay imposed on other hitigants and the court, and the chance of error attributable to possible misuse of the evidence $^{13}$-outweigh the expected factfinding gains from admitting the evidence. Thus, judges must estimate the probative value of evidence in almost every trial and inust learn to weigh that value agamst the potential harm associated with admission of the evidence. The task is easily described but not so easily accoinphished. Estimation of values, both positive and negative, is difficult. And, even if it can be accoinphished with soine acceptable degree of accuracy, weighing the logical value of evidence against its illogical attributes is something akin to balancing apples and oranges - that is, it can be done, but only with difficulty.

While there has been soine recent interest in reconsidering relevance concepts, ${ }^{14}$ aside from articles emphasizimg the utility of inathe1natical models as heuristic devices ${ }^{15}$ or as litigation models, ${ }^{16}$ hittle has

12. Because the concept expressed in the rule is so familiar, most people are surprised to learn that provisions like FED. R. Ev1D. 403 were considered to be most controversial when the first comprehensive evidence codes were proposed. See R. Lempert \& S. SALTZBURG, supra note 8, at 1193-97; Dolan, Rule 403: The Prejudice Rule in Evidence, 49 So. CAL. L. Rev. 220, 221-22 (1976). For the sake of convemence the remainder of the article will refer to the balancing test of Rule 403 either by simply citing the rule itself or by shorthand references to the need to balance the probative value of evidence against its prejudicial effect.

The concept of prejudice is examined in R. LEMPERT \& S. SALTZBURG, supra, at 147-48. Professor Leinpert expands the treatment in Lempert, Modeling Relevance, 75 MiCH. L. Rev. 1021, 1036 (1977), where he defines prejudicial evidence as "any evidence that influences jury" ver. dicts without relating logically to the issue of guilt or innocence" (emphasis in original). I would refine our earlier definition to read: prejudicial evidence is any evidence which affects the trier of fact in a manner not attributable to the probative force of the evidence. This definition makcs clear that evidence that strongly relates to the issue of guilt might also be highly prejudicial.

It is almost amazing that after two hundred years of American cases building on English precedents, Thayer's observation that “[ $t]$ he law furnishes no test of relevancy," J. THAYER, supra note 5, at 265, although inade in another century, is still true. Helpful tools like the inathematical "likelihood ratio," see R. LEMPERT \& S. SALTZBURG, supra, at 149 (expressed non-matheinatically in S. SALTZBuRg \& K. REDDEN, supra note 9, at 102), generally are used only for illustrative purposes. Neither logic nor experience, it seems, is easily translated into a clear-cut evidence rule.

13. Several different reasons explain the possibility of increased error costs. See generally Leinpert, supra note 12.

14. See, e.g., Dolan, supra note 12.

15. See, e.g., Lempert, supra note 12.. Some professors have found students unreceptive to mathematical aids. See, e.g., Ritchie, Book Review, 65 Geo. L.J. 1657, 1664 n.43 (1977).

16. Compare Broun \& Kelly, Playing the Percentages and the Law of Evidence, 1970 U. ILL. L.F. 23, and Finkelstein \& Fairley, A Bayesian Approach to Identification Evidence, 83 HARV. L. REv. 489 (1970) with Cullison, Identification by Probabilities and Trial by Arithmetic (A Lesson for 
been added to the standard law review fare on relevance. ${ }^{17}$ This is unfortunate, since there remains a need for greater understanding of the principles previously described and especially of how to apply them to actual cases. Soine courts still invoke the discredited concept of legal, as opposed to logical, relevancy. ${ }^{18}$ The dispute over the proper approach to rule 403 balancing questions has never been resolved. ${ }^{19}$ Various courts and commentators use the term "irrelevant" to explain exclusion of evidence in situations in which the excluded evidence is relevant but its exclusion is justifiable on other grounds. ${ }^{20}$ Longstand-

Beginners in How to be Wrong with Greater Precision), 6 Hous. L. REV. 471 (1969), and Tribe, Trial by Mathematics: Precision and Ritual in the Legal Process, 84 HARV. L. Rev. 1329 (1971).

17. E.g., James, Relevance, Probability and the Law, 29 CALIF. L. Rev. 689 (1941); Ladd, Determination of Relevancy, 31 TUL. L. REv. 39 (1956); Slough, Relevancy Unmarveled, 5 KAN. L. REV. 1 (1956); Trautman, Logical or Legal Relevancy-A Confict in Theory, 5 VAND. L. REv. 385 (1952).

18. E.g., Cotton v. United States, 361 F.2d 673 (8th Cir. 1966). Sometimes the term "legal relevance" is not used, but the approach is. See, e.g., United States v. Woods, 484 F.2d 127, 135 (4th Cir. 1973) (dissenting opinion), cert. denied, 415 U.S. 979 (1974). For a discussion of "legal relevancy," see R. LEMPERT \& S. SALTZBURG, supra note 8, at 145-46. See also text accompanying note 75 infra.

19. 1 J. WEINSTEIN \& M. BERGER, WEINSTEIN'S EVIDENCE 403 [03], at 403-18 (1975) argues that the proper approach is to "give the evidence its maximum reasonable probative force and its minimum reasonable prejudicial value." Disagreeing, Dolan, supra note 12 , at 233 , recommends that courts "resolve all doubts concerning the balance between probative value and prejudice in favor of prejudice." The few courts that have recognized the need to state a standard have not yet satisfied it. See, e.g., United States v. Robinson, 560 F.2d 507, 516 n.14 (2d. Cir. 1977) (en banc), cert. denied, 435 U.S. 905 (1978). The need for a standard is relatively unimportant in bench trials where judges hear the arguably prejudicial evidence in the course of ruling on adinissibility and know how inuch probative force the evidence has for thein as triers of fact. Although setting a standard for jury trials is not the purpose of this Article, I will continue to discuss the balancing concept. Thus, an explicit statement of how to balance correctly is probably warranted. On one side of the equation belongs the unaximum reasonable probative force of the particular evidence viewed in light of the theories of the parties and their other evidence. Since parties must produce evidence to make a case, and since our evidence system allows juries to make all inferences reasonably deducible froin the proof presented and parties to argue about those inferences, it is evident that the inaximuin probative force of evidence is the cost of exclusion. The judge is not permitted to take action that would force the jury to accept the judge's assessment of the worth of evidence. Jurisdictions that allow judicial comment on the evidence would allow at most a suggestion as to the appropriate assessment of probative value. The other side of the equation should include the likely prejudicial impact of the evidence, rather than the mininum or maximuin prejudicial effect of the evidence. Usually the ininimuin prejudicial effect will be zero, for a jury that follows the instructions of the court and acts logically can, in theory, deal with any evidence. Few of us beheve that jurors will follow instructions perfectly in practice, however, and FED. R. Evid. 403 presumes they cannot. But there is no reason to assume that juries will perform as inperfectly as possible. Rule 403 assuunes, 1 think, that trial judges can identify the likely source of juror misuse of evidence and estinate the harm associated with that unisuse. Courts that suggest that judges state their reasons for balancing make the same assumption. See, e.g., United States v. Dwyer, 539 F.2d 924 (2d Cir. 1976). Thus, the final equation pits maximum probative value against likely prejudicial effect. I have tried previously to outline this argument in S. SALTZBURG \& K. REDDEN, supra note 9, 1978 Supp. at 36.

20. Compare Laughlin, Preliminary Questions of Fact: A New Theory, 31 WASH. \& LEE L. REv. 285, 289 (1974) (confusing reliability and relevance) and Perkins v. Springsten, 557 S.W.2d 343 (Tex. Civ. App. 1977) (holding that hearsay lacks probative value) with Weinstein, Probative 
ing rules resting, at least in part, on a relevance foundation, are attacked by new relevance analyses. ${ }^{21}$ New evidence rules, justified in large ineasure on a relevance analysis, are proposed ${ }^{22}$ and some are adopted, often without careful consideration of relevance issues. ${ }^{23}$ Trial judges still err on basic relevance rulings. ${ }^{24}$ New federal-state issues complicate otherwise basic questions under the Federal Rules of Evidence. ${ }^{25}$ And to the surprise of no one, new and unique relevance problems continually appear in advance sheets ${ }^{26}$ and law journals. ${ }^{27}$

Force of Hearsay, 46 Iowa L. Rev. 331 (I961) (suggesting that hearsay can be highly probative) and Dafoe v. Grants 51, 143 Neb. 344, 9 N.W.2d 488 (1943) (stating that a finding may be based solely on hearsay evidence). Professor Lempert has found that "[c]ourts declare evidence irrelevant for several reasons," one of which is the judicial recognition that jurors inight so badly misestimate the value of evidence that exclusion is required. Lempert, supra note 12, at 1027 . Courts should learn that most estimation problems involve rule 403 , not relevance. The only situation in which a court should declare evidence logically irrelevant because of estimation problems is where no reasonable trier of fact could decide whether the evidence supports or contradicts a proposition.

21. Compare, e.g., FED. R. Evid. 407 with ME. R. Evid. 407. For attacks on the federal approach see Field, The Maine Rules of Evidence: What They Are and How They Got That Way, 27 ME. L. Rev. 203, 217-19 (1975); Comment, The Repair Rule: Maine Rule of Evidence 407(a) and the Admissibility of Subsequent Remedial Measures in Proving Negligence, 27 ME. L. REv. 225 (1975), discussed in S. SALTZBURG \& K. REDDEN, supra note 9, at 168-69; Note, Evidence of Subsequent Repairs: Yesterday, Today, and Tomorrow, 9 U.C.D. L. REv. 421 (1976).

22. See, e.g., S. 1, 94th Cong., 1st Sess. § 1646(b)(2)(B) (1975), discussed in Ordover, Admissibility of Patterns of Similar Sexual Conduct: The Unlamented Death of Character for Chastity, 63 CoRnell L. Rev. 90, 91-94 (1977). Federal Rule of Evidence 412 was added this year to protect rape victims from embarrassment from irrelevant evidence. Pub. L. No. 95-540, enacted Oct. 25, 1978.

23. See, e.g., FED. R. Evid. 609 (a)\&(b); S. REP. No. 93-1277, 93rd Cong., 2d Sess. 14-15 (1974). If prior convictions generally are not of probative value, and if they are possibly prejudicial, is there a reason not to balance to protect the prosecution or civil litigants? No answer appears in the cases that purport to read rule 609 as if it were clear. See note 9 supra. See also text accompanying notes 270-73 infra; Ordover, supra note 22, at 96 n.6. It is possible that with almost no consideration the Congress abohished cliain of custody requirenents in drug cases and other special authentication requirements developed at common law on the theory, arguably incorrect, that the requirements were only relevance rules. Compare S. SAltzBurg \& K. RedDen, supra note 9, at 642-45 with $5 \mathrm{~J}$. WEINSTEIN \& M. BERGER, supra note 19, at 901 (9) [02].

24. See, e.g., United States v. Campion, 560 F.2d 751 (6th Cir. 1977) (holding that the trial court erred in admitting irrelevant evidence); Hopkins v. Baker, 553 F.2d 1339 (D.C. Cir. 1977) (suggesting the trial judge erred in excluding evidence); United States v. Staggs, 553 F.2d 1073 (7th Cir. 1977) (reversing a conviction because evidence was improperly excluded as "irrelevant").

25. See Wellborn, The Federal Rules of Evidence and the Application of State Law in the Federal Courts, 55 Texas L. Rev. 371 (1977).

26. See, e.g., United States v. Myers, 550 F.2d 1036 (5th Cir. 1977) (governunent must disclose alibi rebuttal witnesses prior to trial; threshold requirements must be met before evidence of other crimes admissible; imstruction on flight unjustified because of insufficient evidentiary basis); United States v. Jackson, 405 F. Supp. 938 (E.D.N.Y. 1975) (trial judge had discretion to exclude evidence of defendant's recent felony conviction on condition that defendant not suggest his background was pristime and not utilize prior criminal records of government witncsses; evidence of flight excluded provided defendant enters imto stipulation); Nicholson v. State, 570 P.2d 1058 (Alaska 1977) (government must disclose exculpatory evidence in its control; police not rcquircd to seize evidence not apparently relevant at time of investigation; experiunent must be conducted under substantially similar conditions for its results to be admissible); People v. Hannon, 19 Cal.3d 588, 564 P.2d 1203, 138 Cal. Rptr. 885 (1977) (evidence insufficient to support instruction 


\section{B. Negative Inference Analysis}

This Article responds to the absence of recent attempts to clarify basic relevance analysis by offering some new ideas on a heretofore obscure aspect of relevance. The theme is simply stated: once certain theories of a case are presented and some evidence is offered to support them, triers of fact, especially juries untrained in evidence law and the rules governing litigation, ${ }^{28}$ may expect to lear specific kinds of proof in further support of or in response to the offered evidence. ${ }^{29}$ If their expectations are not satisfied, triers of fact may penalize the party who disappoints them by drawing a negative inference against that party. The problem of negative inferences, then, involves predictable reactions by triers of fact to the presentation of some evidence coupled with the absence of other evidence. Trial judges, when deciding whether to exclude evidence, should recognize that part of proving a case may involve ineeting a jury's expectations about proof - that is, satisfying the expectations of triers of fact who logically reason that a party wliose position is sound should liave evidence on particular points. ${ }^{30}$

A hypothetical problem demonstrates the application of negative inference analysis. ${ }^{31}$ A defendant is charged with the shotgun unurder of a bartender. The question arises whetler the seizure of a shotgun

on inferring consciousness of guilt from suppression of evidence; nexus between defendant and alleged suppression not established).

27. See, e.g., Quint, Toward First Amendment Limitations on the Introduction of Evidence: The Problem of United States v. Rosenberg, 86 YALE L.J. 1622 (1977) (suggesting a twist on FED. R. EvID. 403 to protect speech and association rights).

28. Negative inference analysis applies most significantly to jury trials, because juries generally do not understand the dynamics of pretrial evidentiary rulings as thoroughly as judges. AIthough jurors are aware of the artificiality of the composite evidentiary package presented at trial, their verdicts are often a synthesis of the inferences they draw. The absence of a relevant piece of evidence will mevitably affect this synthesis. Even in judge trials, lowever, negative inference analysis applies. When one judge decides to exclude evidence and another judge acts as the factfinder at trial, the trial judge will draw some inferences from the absence of relevant evidence. And when the same jndge excludes evidence and tries a case, negative inference analysis is a useful tool for clarifying the decisionmaker's understanding of the imterrelationslip of the facts. In both judge and jury trials, the same formal standards of review apply. Although appellate courts in practice may be less inclined to overrule a judge's evidentiary rulings when the same judge lrears the case, theoretically the same ruling sliould be made whoever acts as the trier of fact.

29. The familiar distinction between direct and circumstantial evidence need not be elaborated liere. See R. Lempert \& S. SALTZBURG, supra note 8, at 142-43. It should be sufficient to note that the evidence problems addressed by the Article imvolve inferences from the absence of evidence, or problems of circumstantial proof.

30. This is of special importance when the judge considers whether to prevent evidence from going to the jury, but careful trial judges should recognize that they too may have logical expectancies about proof and slould rule accordingly. See, e.g., Clark v. Hilde Const. Co., 576 P.2d 1112 (Mont. 1978).

31. See R. Lempert \& S. SAltzBuRg, supra note 8, at 154 (Problem III-4). In the materials the problem is framed more generally, with the hope that more specific facts will be requested in class, thereby setting the stage for a discussion that covers, at a minimum, the point made in the text. 
from the defendant's house at the time of arrest is relevant, assummg that: (1) the crime took place in Southwest Virginia; (2) possession of shotguns is commonplace in this region; (3) ballistics tests could not determine that any one shotgun was the murder weapon; and (4) the jurors were selected from the Southwest Virgima community and have some knowledge of the prevalence of shotguns. A common mitial reaction is to exclude the evidence as irrelevant because of the weak link between the defendant's weapon and the crime. But, as Professor Lempert recently argued, exclusion has undesirable implications:

[F]ailure to introduce evidence of ownership might harm the prosecution's case, since the jury might treat the absence of such evidence as a fact having probative value. Indeed, for a juror who was certain that the prosecution would introduce evidence of the defendant's access to a shotgun if the defendant had access, the lack of evidence would be reason to acquit. ${ }^{32}$

Thus, the shotgun is relevant evidence not only because it demonstrates the defendant's access to a weapon necessary to commit the crime, but also because its exclusion has a tendency to dennonstrate, by negative inference, the defendant's lack of access to such a weapon. The probative value of the shotgun must be judged cumulatively, by analyzing both its value as positive evidence and the significance of its absence.

A second hypothetical further highlights the poimt. ${ }^{33}$ A gynecologist-obstetrician is accused of performing an illegal abortion. The prosecution wants to introduce into evidence cervical dilators, which could be used to perform abortions, found in her office. The dilators are relevant and should be admitted because, although the same instruments are likely to be found in the doctor's office even if she were acting legally, the jury well niay expect such evidence to be offered and, as a result, exclusion makes the prosecutor's case appear weaker than it really is.

Admission of the evidence could give rise to another inference: that cervical dilators are particularly persuasive evidence that the doctor performs abortions. This negative inference can be counteracted, however, unlike exclusion of the evidence. The defense can place the discovery of the cervical dilators in context by showing they are ordinary gynecological equipnient. This reduces the danger of prejudice against the defendant. But the inferences drawn from the absence of the evidence are irrenrediable, particularly if the defense is permitted to comment on the lack of evidence.

32. Lempert, supra note 12 , at 1047 . Arguably, the jury might be so suspicious about the absence of a gun that it would be quick to convict, rather than to acquit. Whatever the response when the evidence is excluded, it is inferior to the response when the evidence is admitted.

33. See R. Lempert \& S. Saltzburg, supra note 8, at 154 (Problem 111-6). A similar problem can be found in K. Broun \& R. Meisenholder, Problems in Evidence 2-3 (1973) (Problem 1-4). 
The relevance of evidence, then, can be determined both positively and negatively. The dilators are relevant first, as positive evidence, and second, as evidence counteracting a negative inference. This leads to a second application of negative inference analysis: judging the probative value of the lack of certain evidence as evidence in itself. For example, if the government did not find any dilators at the gynecologist's office, that fact is relevant for the same reason the fact of their discovery is. The absence of cervical dilators inay demonstrate the defendant's inability to perform abortions. Alternatively, their absence may suggest that the jury sliould not believe that the defendant practices gynecology at that office. Both the prosecution and the defense can try to persuade the jury of the implications of the fact, thereby directing the jury's inferences. Whatever the jury concludes, lowever, the absence of the evidence is relevant because it affects the likelihood that the defendant performs illegal abortions.

\section{The Administrability of Negative Inference Analysis}

Trial judges will make better relevance rulings if they pay attention to the expectations of juries. Whether they clioose to admit evidence to satisfy jurors, clioose to reject all of the evidence, or clioose to admit part and reject part with or without a jury instruction, judges must be aware of juror expectations to make a proper clioice. Sucli an awareness does not make judicial decisions easier. But judges and other policymakers who have not yet focused on the tlieme are missing important considerations in making evidence rulings and drafting rules to govern litigation.

The liypotheticals demonstrate that it is predictable in some litigation contexts that the failure to admit proof expected by a jury may hurt a party. Can we confidently identify these contexts? The answer must be "yes," if our general relevance rules are workable. Judges who are capable of evaluating the logical relationship of evidence to a case and of estimatimg the potential danger associated with evidence should be capable of determining when the absence of proof is likely to disappoint a jury and liurt a party. Just as " $[t]$ he relevance of a given piece of circumstantial evidence inust be determined by the trial judge in view of his or lier experience, judgment and knowledge of liuman inotivation and conduct," 34 the likelihood that a jury will draw negative inferences can be determined in view of the saine factors.

American courts liave already taken account of the negative inferences that juries might draw from the absence of certain kinds of proof in a few narrow situations. For exainple, criminal defendants can demand an instruction that the jury not draw negative inferences from a

34. United States v. Williams, 545 F.2d 47, 50 (8th Cir. 1976). 
defendant's failure to testify. ${ }^{35}$ Similarly, the Supreme Court has decided that prosecutors cannot ask the jury to consider the criminal defendant's silence at trial as evidence. ${ }^{36}$ Rules prohibiting comment on the exercise of nonconstitutional evidentiary privileges are of similar import. $^{37}$

Conversely, in some jurisdictions, litigants can demand a specific instruction that a jury inay draw adverse inferences from the failure of a party to offer evidence. Although these rules are ever less common today, ${ }^{38}$ soine courts continue to follow the rule that

[w] hen it would be natural under the circumstances for a party to call a particular witness, or to take the stand himself as a witness, ${ }^{39}$.or voluntarily to produce documents or other objects in his possession as evidence, and he fails to do so, . . . his adversary [is permittcd] to use this failure as the basis for invoking an adverse imference. ${ }^{40}$

In some of these jurisdictions, courts give standard instructions on the significance of the failure to produce evidence, while in others the trial judge has the discretion to give sucl instructions. ${ }^{41}$

Although these rules recognize the inplications of negative inferences, the analysis involved is materially different from that required to reflect the significance of jurors' expectations im every case. Established rules identify the circuunstances in which the judicial system recognizes nonproduction of evidence as acceptable, and perhaps desirable, behavior that is not to be discouraged by permitting or encouraging adverse inferences to be drawn from nonproduction. Such circumstances are contrasted witl those in which the judicial system recognizes nonproduction as unacceptable behavior that is to be discouraged by allowing the threat that adverse inferences will be drawn to work as an incentive for production. This Article focuses not on those litigants whose inclination is not to produce evidence, but on those who wish to

35. This is the prevailing view. See Y. Kamisar, W. LAFave \& J. Israel, Modern CrimiNAL Procedure 1349 (4th ed. 1974). There is evidence that the instruction does not work. See, e.g., Note, To Take the Stand or Not to Take the Stand: The Dilemma of the Defendant With a Criminal Record, 4 Colum. J.L. \& Soc. Prob. 215, $221-22$ (1968). Defendants may be blessed with such an instruction even if they object to it. See, e.g., Lakeside v. Oregon, 435 U.S. 333 (1978).

36. Griffin v. California, 380 U.S. 609 (1965). Prosecutors can tread close to the line, however, without violating Griffin. See, e.g., C. MCCoRMICK, supra note 11, at 277-78 \& n.27; Annot., 14 A.L.R.3d 723 (1967).

37. See, e.g., proposed federal evidence rule 513, 56 F.R.D. 183, 260 (1972).

38. See Saltzburg, The Unnecessarily Expanding Role of the Trial Judge, 64 VA. L. REV. 1, 34 (1978).

39. Unless the instruction is impermissible on constitutional grounds. See note 36 and accoinpanying text supra. See also State v. Sutton, 562 S.W.2d 820 (Tenn. 1978).

40. C. MCCoRMICK, supra note 11, at 656 (footnotes omitted; footnote 39 added). The commentary urges caution in applying the traditional rule. Id. at 657-59. Some courts require counsel to get permission from the court before commenting on a inissing witness. See, e.g., Brown v. United States, 383 A.2d 1082 (D.C. App. 1978).

41. Id. at 659 . 
bring evidence forward and may be prevented from doing so because judges misestimate the value of the evidence.

II

\section{The Case-by-Case Application of Negative INFERENCE ANALYSIS}

\section{A. Judging Probative Value}

A simple example of applying negative inference analysis to weigh the probative value of evidence will serve as a useful introduction to this discussion. In United States v. Riley, ${ }^{42}$ a former national bank examiner was convicted of misapplying funds of a national bank. Riley conceded that he induced the bank to issue cashier's checks for his remittance before he paid for thein, but he sought to show that the transactions were regarded as inforinal loans or extensions of credit to a bank officer. He proffered evidence of eighty other instances during the same period of time in which the bank had issued cashier's checks without contemporaneous payment, but the trial judge excluded the evidence. Reversing the conviction, the United States Court of Appeals for the Fifth Circuit wrote that "[a]lthough the trial judge is traditionally accorded a wide range of discretion in the admission of evidence, ... . it is axionatic that such discretion does not extend to the exclusion of crucial relevant evidence establishing a vahid defense." 43 Without the proffered evidence, a jury hearing evidence about banking practices and naturally expecting to learn of any relevant loan practice would be much less likely to accept the defense's characterization of the financial transactions than if evidence of normal practices were offered. The exclusion of the defense evidence created the negative inference that the transactions were irregular and therefore suspect.

State v. Ballard ${ }^{44}$ illustrates the utility of negative inference analysis in judgimg the relevance of rebuttal evidence. Ballard was tried for first degree burglary and felonious assault with inalice aforethought for his participation in a macabre attack evidently arranged by the wife of

42. 550 F.2d 233 (5th Cir. 1977). See also United States v. Abascal, 564 F.2d 821 (9th Cir. 1977); United States v. Garvin, 565 F.2d 519 (8th Cir. 1977). The analysis that I suggest here is especially useful in analyzing offers of evidence intended to show the occurrence of similar events. For example, when evidence of more than one accident is offered to show neghigence or a defective condition, if the negligent act or the inadequate condition is likely to affect more than one person, jurors may expect to receive evidence about other injuries. Their expectations should be considered in determining whether to admit evidence.

43. 550 F.2d at 236 (citation omitted). See also United States v. Benveniste, 564 F.2d 335 (9th Cir. 1977); United States v. Lambert, 580 F.2d 740 (5th Cir. 1978); United States v. Wolfson, 573 F.2d 216 (5th Cir. 1978). But see Umited States v. Wigoda, 521 F.2d 1221 (7th Cir. 1975), cert. denied, 424 U.S. 949 (1976), criticized in S. SAltzBurg \& K. Redden, supra note 9, at 126.

44. 554 S.W.2d 459 (Mo. Ct. App. 1977). See also Moore v. Commonwealth, 569 S.W.2d 150 (Ky. 1978). 
the victim. The prosecution presented evidence that the defendant ran from the police. The defendant wanted to counter with evidence "that he voluntarily turned himself in . . . to let the jury know this in mitigation of the inference against defendant which the prosecution sought to draw from the fact of defendant's flight." 45 The trial judge admitted the evidence and received the appropriate approbation of the appellate court. ${ }^{46} \mathrm{Had}$ the evidence been excluded, the negative inference associated witl flight ${ }^{47}$ would have been nore powerful than it should have been. ${ }^{48}$

These two cases demonstrate that judges should consider potential juror expectations in order properly to determine the relevance of evidence wlien there are no strong policies favoring exclusion. The following section expands the discussion to show that negative inference analysis leads to a more accurate appraisal of the cunnulative probative value of evidence when the probative value is balanced against the potential prejudice created by admission, as under federal rule 403 .

\section{B. Balancing the Probative and Prejudicial Qualities of Evidence}

Of the many recent cases decided under the Federal Rule of Evidence 403, none better illustrates the importance of negative inferences and the failure of judges to take them into account than United States $v$. Robinson. ${ }^{49}$

The evidence im Robinson showed that four inen had robbed a New York City bank of more than $\$ 10,000$. Approximately ten weeks later, Robimson was arrested after another alleged participant in the crime, Simon, was arrested, confessed, and named Robinson as a coconspirator. ${ }^{50}$ At the time of his arrest Robinson possessed a .38 caliber revolver. Simon testified that Robimson, two named others, and Simon had planned and carried out the robbery of a branch bank close to Robimson's place of einployment. A crucial part of Simon's testi-

45. 554 S.W.2d at 462 .

46. Id. Appellant was convicted on both charges, but the robbery charge was reversed on appeal on the ground that the government failed to prove illegal entry.

47. "Flight has generally been received as evidence of guilt." E. ClearY \& J. STrono, Evidence: Cases, Materials, Problems 622 (2d ed. 1975). But see United States v. Myers, 550 F.2d 1036 (5th Cir. 1977).

48. See also Parr v. State, 557 S.W.2d 99 (Tex. Crim. App. 1977). If the trial judge does decide to exclude evidence, she should be careful to prevent unfair argument concerning the absence of proof. See, e.g., Harbin v. Interlake Steamship Co., 570 F.2d 99 (6th Cir. 1978); State v. Havens, 264 N.W.2d 918 (S.D. 1978). See also, e.g., Havens v. Solem, 455 F. Supp. 1132 (D.S.D. 1978).

49. 560 F.2d 507 (2d Cir. 1977) (en banc), rev'g 544 F.2d 611 (1976), cert. denied, 435 U.S. 905 (1978).

50. Simon named Robinson as a coconspirator on the day of his arrest and agam when he identified Robinson in bank surveillance films. 560 F.2d at 510 n.3. But there was some evidence that the government suggested Robinson's name to Simon while interrogating him. Id. at $520 \mathrm{n} .2$ (Oakes, J., dissenting). 
mony was that at the time of the robbery Robinson possessed either a .38 caliber revolver or a gun that looked like a .38. Without the correspondence between this allegation and the discovery of the .38, Simon's testimony had little corroboration. The trial judge admitted testimony about the .38 caliber gun seized from Robinson despite a rule 403 defense objection. But the gun itself was never shown to the jury, and the judge gave a limitimg instruction that confined the jury's use of the testimony to "whatever value, if any, it has on the issue of defendant's identity as one of the robbers" 1 and barred the jury from drawing "any conclusions or inferences or engag[img] im any speculation as to the defendant's character or reputation on the basis of this testimony." 52

Robimson was convicted of bank robbery, although it took one inodified "Allen charge" followed by another similar, but shorter, charge to move the jury from 11-1 for conviction to unanimity. ${ }^{54}$ The introduction of the weapons evidence probably contributed to the verdict, since, in a previous trial for the same offense when testimony about Robinson's gun was not introduced, the jury hung 8 to 4 for conviction. ${ }^{55}$ A panel of the United States Court of Appeals for the Second Circuit held, two to one, that introduction of the evidence was reversible error, but an en banc court affirmed the trial judge. ${ }^{56}$

The Second Circuit judges all agreed that the evidence was relevant, but they disagreed on whether the trial judge had properly weighed its probative and prejudicial quahities. Judge Mansfield, writing for the majority, concluded that the evidence established a "remarkable coincidence" with respect to the calibers of the robber's weapon and Robinson's, thus corroborating Simon's testimony, ${ }^{57}$ and that the evidence was also admissible to show Robmson's opportunity to commit the offense. ${ }^{58}$ Although he recognized the possible prejudicial effect of the evidence, Judge Mansfield observed that the trial judge should not be reversed because of a rule 403 ruling "unless he acts arbi-

51. Id. at 511 n.4.

52. Id.

53. See Allen v. United States, 164 U.S. 492, 501-02 (1896), in which mimority jurors were encouraged to reevaluate their own positions in light of the reasonableness of the opinions of the other jurors.

54. When the conviction on the bank robbery cliarge was returned, the other counts of the indictment charging conspiracy and armed bank robbery were dismissed either without opposition by the government or with its consent. Compare 560 F.2d at $509 \mathrm{n.2}$ with id. at 512 .

55. Different judges tried the two cases. The first judge did not have before him Simon's testiniony about the assembling and calibers of the weapons. Id. at $511,516 \mathrm{n} .11$.

56. Judge Feinberg dissented on the ground that rehearing en banc slould not lave been granted. Id. at 526-27. The panel majority also dissented.

57. Id. at 512 .

58. Id. at 513 (relying on FED. R. Evid. 404(b)). 
trarily or irrationally,"59 and he found that the trial judge's actions were "neither unreasonable nor arbitrary." 60 Judge Oakes, in dissent, concluded that the inferential jump from possession of a .38 caliber gun ten weeks after the robbery to the conclusion that this was the gun that was used in the robbery was too weak to justify informing the jury of something so prejudicial. ${ }^{61}$ The gun, he noted, was "undistinctive and unremarkable," and the ten week delay, he argued, cast doubt on the persuasiveness of the majority's claim of coincidence, especially in light of the number of 38 caliber weapons in the possession of the public. $^{62}$

In reaching their conclusions, neither Judge Mansfield nor Judge Oakes considered the effect of admission or exclusion of the evidence on jurors' inferences. The district court's resolution of the rule 403 objection at trial, however, reflects a greater awareness of the problem. ${ }^{63}$ The trial judge delayed the presentation of the firearm evidence in order carefully to balance the impact of the evidence. The judge also made an effort to protect the defendant froin "unfair" prejudice ${ }^{64}$ by

59. Id. at 515 .

60. Id. Selection of the "neither unreasonable nor arbitrary" standard of review is a major fault in the majority opinion. See id. at 525 (Gurfein, J., dissenting). The evidentiary rulings of trial judges should reflect greater consistency than the standard can enforce. As the judges voting for en banc reconsideration imphicitly recognized, it is important for trial judges to know that careful findings for the record to support rule 403 balancing decisions will be respected by a court of appeals unless the trial judge is plainly wrong. Nevertheless, some form of clearly erroneous test resembling FED. R. Clv. P. 52 is inore appropriate than the inajority's test. See, e.g., United States v. Johnson, 558 F.2d 744 (5th Cir. 1977), eert. denied, 434 U.S. 1065 (1978). Read literally, the majority ties its own hands so that in future cases it cannot recommend against admitting certain forms of highly prejudicial evidence unless it concludes that it is irrational to do so. See, e.g., United States v. Albergo, 539 F.2d 860 (2d Cir.), cert. denied, 429 U.S. 1000 (1976). An appellate court should inform trial judges when it is better to reject than to adinit evidence. When an appellate court, making all the usual assumptions in favor of the trial court's ability to judge the intonation and demeanor of witnesses and the emotional reaction of the jury, finds its reasons clearly madequate to justify a ruling, the court should reverse if the trial judge clearly erred in balancing the probative value of the evidence against its substantial prejudicial effect. See United States v. Robinson, 560 F.2d at 525-26 (Gurfein, J., dissenting). For a critical discussion of Robinson, see Weinstein, Three Years of the Federal Rules of Evidenee, N.Y.L.J., Feb. 7, 1978, at I, col. 2.

61. Judge Oakes was skeptical of Simon's credibility and commented that "the faet that appellant was found with a .38 caliber gun after Simon had said such a gun was prepared for use in the robbery may show nothing more than that Simon knew that appellant owned a .38." 560 F.2d at 520. There is reason to question whether an appellate court's job is to assess a witness' credibility, however. Usually this is left to the jury.

62. Id. at $520-22$. This point was made more powerfully in Judge Oakes' panel opinion. 544 F.2d at 617-18.

63. The trial judge did not rely on an opportunity theory, and it is difficult to tell from the court of appeals' majority opimion whether its corroboration theory is identical to or different from the trial judge's identity theory. For a discussion of the legitinacy of an appellate court using a different evidentiary theory from the trial judge's, see Saltzburg, Another Ground for Decision-Harmless Trial Court Errors, 47 TEMP. L.Q. 193 (1974).

64. See Dollar v. Long Mfg., N.C., Inc., 561 F.2d 613, 618 (5th Cir. 1977), cert. denied, 98 S. Ct. 1648 (1978); Depew v. Hanover Ins. Co., 438 F. Supp. 358, 360 (E.D. Tenn. 1977). 
instructing the jury to consider the evidence solely on the issue of identity in an atteinpt to minimize the prejudicial effect of the jury's opinion of the defendant's character. ${ }^{65}$ This resolution is proper if the probative value of the evidence outweighed the danger that the jury instruction would not be effective.

The factual context of Robinson requires an examination of the relationship of a discrete piece of evidence to the evidence in the case as a whole. The probative value of Robinson's possession of the .38 was greater than simply that he had access to a weapon like that used in the robbery. Without the evidence, the government's case would have been substantially weakened in two subtle ways. After viewing the other evidence, the jury would have expected some proof of access to a .38 caliber weapon, and its disappointinent at not hearing such evidence inight have generated unwarranted inferences that could have determined the result. ${ }^{66}$ Moreover, the rest of Simon's testimony would have been less persuasive without more corroboration. The judge should have weighed these two factors to appraise accurately the probative value of adınitting the evidence. The addition of the jury expectation arguinent to Judge Mansfield's coincidence arguinent substantially enhances the case for admission.

There remain weaknesses in the trial judge's ruling, but they are not those emphasized by Judge Oakes. The two principal problems relate to the foundation laid by the government in an effort to deinonstrate the conditional relevance ${ }^{67}$ of Robinson's possession of the .38 cahber weapon. First, Simon's testimony that the robber identified as Robinson had a .38 cabiber gun was weak; Simon was the only witness and part of his testimony related to a weapon that "looked like" a .38. Second, although Simon claimed to have seen the robber identified as Robinson hand his gun to another robber after completion of the crime, the bank photos cast doubt on Simon's story. The photos did not show that the robber identified as Robinson used a weapon.

With these weaknesses in mind, the trial judge had a choice of several resolutions of the rule 403 objection. The judge could have excluded all evidence about weapons, thereby avoiding any possible prej-

65. 560 F.2d at 511 n.4.

66. For a juror's own statement on the importance of having evidence of access to a gun, see Parmley, Waiting for Perry and Della, DISTRICT LAWYER, Aug./Sept. 1978, at 34-35. See also Thompson v. State, 85 Wis.2d 134, 265 N.W.2d 467 (1978). In a number of cases involving evidence of other crimes and FED. R. EvID. 404(b), appellate courts have required some substantial showing of a government need for the evidence. See, e.g., United States v. Bloont, 538 F.2d 704, 708-09 (5th Cir. 1976), cert. denied, 429 U.S. 1074 (1977). There is a difference between most of these cases and the Robinson case. In other cases the "need" to which the courts refer is the usual dependence of parties on probative evidence to prove their cases, whereas in Robinson the government's "need" includes this dependence and nore-ie., the need to respond to the negative inference predicted to result from absence of the evidence.

67. See generally R. LEMPERT \& S. SALTZBURG, supra note 8, at 143-44; Saltzburg, Standards of Proof and Preliminary Questions of Fact, 27 STAN. L. Rev. 271, 272 n.3 (1975). 
udicial effect and bypassing the negative inference problem that Simon's evidence presented. But without this detail, the jury might not liave believed any of Simon's testimony. Alternatively, the trial judge miglit have determined that no negative inference of any importance would be drawn if testimony about the gun seized from Robinson were excluded, since the bank films cast doubt on whether Robinson had a gun. There was also testimony that he lianded his gun to a coparticipant during the escape, which would minimize the jury's expectancy. But Simon's testimony was crucial to the government's case, and the doubts about his credibility raised by the bank surveillance films unade it more, not less, important for the government to remove any limgering negative inference. ${ }^{68}$

Robinson is a hard case. The balance could liave gone either way and there is little point in advocating eitler view. The trial judge assured that the jury's expectations were satisfied by the admission of the evidence and thereby protected the government's case. The jury imstruction minimized the evidence's prejudicial quality as inuch as possible. This resolution reflects an understanding of the dynamics of jury expectations. Any other weaknesses with the judge's ruling are not relevant to this discussion. The important poimt here is that by thinking about negative inferences we can improve on the analysis of the Second Circuit judges. ${ }^{69}$

Anotlier bank robbery case, United States $v$. Williams, ${ }^{70}$ demonstrates that even when appellate courts realize the problems associated witll negative inferences, it may be dangerous for thein to speculate about negative inferences witliout full development of issues at the trial level. The relevant facts are that two men with bushy hair and mustaches robbed a District of Columbia bank of approximately $\$ 5,800$, including soine bills wrapped in pink bands inarked "Public Nat. Bank" with the date and the nuinber 30 . Bank surveillance cameras photograplied the men. Three days later two government agents investigating another crime searched an apartinent shared by one Roland Wolford and the sister of the defendant, Williams. They found two packets of inoney bound with the bank wrappers. Wolford was ar-

68. In other words, the government needed to show that its evidence was consistent with Simon's version of the events to avoid the jury's inferring that Simon was wrong in crucial respects. The bank film suggested that the person identified as Robinson inay havc been unarmed. At least the evidence of the .38 caliber gun seized froin Robinson supported Simon. Had the parties focused directly on the negative inference problein, they could have clarified whether the person whoin Simon identified as Robinson ever took his gun back from the person to whom he had passed it. Because Robinson had offered to provide the getaway car and because his fingerprint was found in the back seat, a jury easily could have assumed that he reacquired the gun before abandoning the vehicle.

69. My analysis would have caused Judge Oakes, for exaunple, to focus on the possible threat of a negative inference to the government's case.

70. 561 F.2d 859 (D.C. Cir. 1977). 
rested and pleaded guilty. Williams was arrested two weeks after the robbery. His head was shaved, he had no mustache, and he gave the police a false name. At line-ups, one bank teller could not identify anyone and a bank customer identified someone other than Williams, but two bank employees identified Williams. ${ }^{71}$ At trial these two witnesses again identified Williams and his coat, although one witness had made a pretrial statement about the coat that was slightly inconsistent with the in-court identification. Other trial evidence mcluded 200 frames of bank surveillance film, three defense alibi witnesses, and the money found in the apartment in which, the jury was told, Williams' sister lived.

Williams was convicted, but the United States Court of Appeals for the District of Columbia Circuit reversed, two to one. Judge (then Chief Judge) Bazelon, writing for the majority, found that Williams' connection with his sister's apartment was not established, nor was his relationship with Wolford proved. His sister testified that she saw "very hittle" of her brother around the time of the robbery. According to Judge Bazelon, "Williams' blood relationship with one co-occupant of the apartment was an exceedimgly thin strand to support the threshold requirement of relevance."72 Even assuming relevance, the evidence was far more prejudicial than probative "because the jury was not told that the other occupant of the apartment had admitted participating in the robbery and may well have been solely responsible for placing the money in the apartment without Williams' participation or knowledge."73

The late Justice Tom Clark, sitting by designation, dissented. He observed that Williams' sister testified 'that Williams seldom frequented the apartment and that Wolford was her common law husband and shared the apartment and its furnishings with her, including the dresser in the master bedroom in which the money was found,"74 and that the jury rejected the "seldom" adverb and the implicit pointmg of the finger at her common law husband.

Applymg the relevance standard described earlier, the evidence of where the money was found was clearly relevant. Judge Bazelon's suggestion that there is a "threshold requirement" of relevance smacks of a "legal relevance" analysis and is inconsistent with federal rule 401,

71. One had picked his photograph from an array compiled by the FBI two days after the robbery. 561 F.2d at 860 .

72. Id. at 862 .

73. Id. The last part of the instruction that Judge Bazelon would have required-a statement by the court that Wolford might have been solely responsible-appears to be an argument that the defense lawyer should have made, not the court.

74. 561 F.2d at 865 . Justice Clark may have been drawing his own inferences about the meaning of what was said, rather than reporting Williams' sister's words as spoken. See id. at 869 (MacKinnon, J., statement). 
which demands only that evidence have some tendency to make a fact m issue more or less probable. Although the jury was instructed to disregard Wolford, ${ }^{75}$ it could not ignore his relationship to the case. The evidence of the inoney, with the bank films, strongly suggested that Wolford was one robber. Williams' sister admitted that Williams had visited her apartment. This estabhshed some relationship between Williams and Wolford as well as between Williams and the inoney. Thus, the money itself had some probative value in the case. The jury was permitted to decide how convincingly the prosecution had established the connections, and the defense was permitted to try to imfluence that decision with evidence minimizing the connections.

Had the government been content to show only that the money was found in appellant's sister's house, and had the defense been barred from eliciting testinnony from the sister that she shared the apartment with Wolford and other testimony suggesting Wolford's guilt, the defense would have had a valid complaint. In part, the coinplaint would have focused on the negative inference that results from this truncated evidence: an inference that only Williams could have left the evidence in the apartment. But at trial the relationships of the various people to the apartment were fully explored, effectively assuring that no inference that Williams was the only male connected with the apartment would be drawn.

There remaims the issue of the prejudicial effect of the evidence as presented. Judge Bazelon's speculation that the failure to disclose Wolford's confession resulted in negative inferences damaging to Willians manifests an awareness of the significance of jury expectations. But the judge's analysis failed to take adequate account of how the absence of Wolford's plea fit into the factual context of the case.

The Williams jury could have drawn several possible negative inferences, of which the appellate court's is not the most compelling. Without Wolford's plea, the jury could not have been certain that Wolford was guilty. The jury's uncertainty has several conflicting effects. ${ }^{76}$ All of the government's evidence related to two robbers. If the jury were inore certain that Wolford was one of the two, Williams' connection with Wolford might have been more powerful evidence of his participation in the robbery. The jury also would have been inore certain

75. Apparently the government agreed not to call Wolford as a witness in exchange for his plea. Id. at 865 n.3 (Clark, J., dissentimg).

76. The sister's testimony arguably accomplisled all that introduction of the plea could accomplish and more-more in the sense that Wolford's exact role remained vague and the odds increased that a reasonable doubt would be created. It comes as no surprise that the defense lawyer did not ask to lave the guilty plea revealed. See United States v. Aldace, 564 F.2d 706 (5th Cir. 1977). The defense played as well as the game can be played, minimizing the jury's sense of confidence that it understood the various participants' roles in the case and their relationship to each other. 
that Wolford had not received the money after the robbery. Furthermore, Wolford's plea was not necessarily an admission that he put the inoney in the dresser. The jury might have concluded that Wolford and Williauns hid the money jomtly in an apartment of a person related to both (or even that Williams had used his access to the apartment to hide the money himself, although this would have been most unlikely).

On the other hand, the jury might have drawn several inferences against Williams from the absence of the evidence of the bargain with Wolford. Doubts about Wolford's participation in the robbery could have led the jury to speculate that only Williams was responsible for placing the money in the drawer, as Judge Bazelon argued. The jury might have surmised that Wolford, not named as a defendant, either was innocent or that, if guilty, he had named Williams as his partner and the government prosecuted only the participant who was most culpable.

The sigmificant point is that the failure to disclose Wolford's plea could have had a number of effects, but the court of appeals focused on only one. Another major flaw is that neither the defense attorney nor the prosecutor attempted to have the evidence admitted, nor did either request that the judge read a stipulated instruction to the jury. ${ }^{77}$ The defense attorney might have evaluated the possible effects on jury speculation of excluding the evidence and determined, quite reasonably, that Williams' chances for acquittal were better without the evidence. By requiring that the evidence be presented, the appellate court well may have contradicted the defense attorney's judgment without a convincing reason for doing so. The lack of a complete development of the issue at trial may have misled the reviewing court. In general, if trial judges manifest an awareness of negative inferences and rnle on the issue, the reviewing court's role will be easier and its judgment more accurate. But in this case the lack of a trial record apparently resulted from a defense attorney's strategy, not from the trial judge's indifference to the issue. The court of appeals did not understand all of the possible jury inferences and their effect on the rest of the case, nor did it examine the role of the defense attorney in failing to present the evidence. A better approach would have been to remand the case to the district court for a determination whether the defendant was unfairly treated by the absence of evidence.

77. It is possible that despite the instruction to disregard Wolford the jury might have speculated about his absence. See United States v. Morgan, 58I F.2d 933 (D.C. Cir. 1978) (holding that the district court improperly excluded evidence in a possession of narcotics with intent to distribute case that would have suggested that someone other than the defendant was distributing the drugs). There is no reason in Williams to think that such speculation would have been more likely to disfavor one side than the other. But to the extent it would have had a disproportionate impact, a more elaborate jury instruction could have been given upon request. 
A final case, United States $v$. Wilson ${ }^{78}$ presents a situation in which negative inference analysis can be used to judge the prejudicial quality of evidence rather than to assess its probative value. Wilson also demonstrates the utility of this analysis in generalized fact patterns as well as in particular instances like Robinson or Williams.

In Wilson's prosecution for rape, the trial judge ruled that the government could ask the defendant whether he had ever been convicted of a felony, but could not divulge that the prior conviction, rendered by a West German court, also was for rape. On appeal the defendant complained that, because criminal defendants are afforded inadequate procedural protections im West German courts, admission of any evidence of the prior conviction was error. The United States Court of Appeals for the Fourtlı Circuit upheld the trial judge.

Both the trial and appellate judges failed to consider the effect of the prior conviction on probable jury expectations. When the jury in a sexual offense trial hears evidence of the defendant's prior conviction, but not of the specific felony committed, it may be inclined to assume that the prior conviction was also for a sex offense. Such an assumption is understandable when the jury knows little about the defendant aside from his conduct tliat led to his prosecution for a crime like rape, which is commonly and appropriately viewed as repulsive. ${ }^{79}$ While the assumption would have been correct in Wilson, it also would liave been extremely inflammatory, ${ }^{80}$ and if the jury actually made the assumption, keeping the specific offense secret had little practical significance. The circuit court should have recognized that even absent proof of the specifics of a prior conviction, juries still may draw imferences about these specifics against certam classes of defendants, mcluding alleged sexual offenders. This is not really a problem of negative mferences attributable to the absence of evidence, but lurking im the background is such a problem.

Negative inference analysis strengthens the argument for exclusion on the basis of prejudice. In Wilson type cases the defendant generally cannot introduce evidence to ininimize the jury's tendency to draw a negative inference because often any defense evidence will confirm the jury's liypothesis. Admission of the prior conviction without specifying

78. 556 F.2d 1177 (4th Cir.), cert. denied, 434 U.S. 986 (1977). For a more sensitive treatment of the defendant's plight with respect to ncgative inferences, see United States v. Calhoun, 544 F.2d 291 (6th Cir. 1976).

79. See H. Kalven \& H. Zeisel, The American Jury 396 (1966); Gregg, Other Acts of Sexual Misbehavior and Perversion as Evidence in Prosecutions for Sexual Ofjenses, 6 ARIz. L. Rev. 212 (1965). Cf. People v. Thomas, 20 Cal. 3d 457, 573 P.2d 433, 143 Cal. Rptr. 215 (1978) (special protection necessary against evidence of prior sex offense being introduced to jury).

80. See, e.g., Gordon v. United States, 383 F.2d 936, 939 (D.C. Cir. 1967), cert. denied, 390 U.S. 1029 (1968). Courts have assumed for some time, and with some justification, that sex offenders are different from other criminal offenders. See R. Lempert \& S. SALTzBura, supra note 8 , at $220-21$. 
the charge does not protect the defendant either. Jurors will only sometimes appreciate the difference between a previously convicted offender presently charged with a sexual assault and a previously convicted sex offender. Often they will expect that the defendant will bring to their attention any mitigating aspects of a prior conviction, when one is offered. As a result, they probably will draw a damaging inference. And because the defense cannot introduce evidence to negate it, and there are no other effective means to limit the prejudice, it is mipossible to protect defendants after the admission of evidence like that im Wilson. This suggests that the trial judge's ruling and the affirmance by the court of appeals may have unfairly and improperly prejudiced Wilson.

Robinson, Williams, and Wilson can only suggest the multitude of situations that require negative inference analysis. This Article cannot catalogue all possible applications because a consideration of what factfinders will infer from the absence of a piece of evidence goes to the heart of relevance analysis. It does, however, recommend that judges analyze more carefully the facts of each case. This section should demonstrate that awareness of negative inferences will not smiplify the task of trial and appellate judges, but it should improve the quality, not only of relevance and balancing rulings made in trial courts, but also of appellate review of these rulings. The next section moves from ad hoc decisionmaking to analyze nore general rules of admission and exclusion that have been developed to simplify the trial judge's task by providing rules to govern certain familiar classes of cases. My analysis will suggest that awareness of negative inferences and concern for jury expectations indicates that many of the standard rules do serve to assure litigants of a fairer trial than they otherwise might receive, but for reasons that have been largely ignored until now.

III

\section{Negative INFERENCES AND EVIDENCE Rulemaking}

The previous section has demonstrated, I hope, the wisdom of identifying juror expectations and working them into a case-by-case relevance analysis of particular offers of proof. If so, it is possible now to step beyond individual cases to examine the relationship of juror expectations to the designing of rules of evidence. Since the hearsay rule is "[p]erhaps the best known feature of Anglo-American law,"81 an analysis of several hearsay exceptions-which, this Article argues, rest im part on a recognition of the problem of negative inferences associated with disappointed juror expectations - should be an appropriate way of testing the point.

81. E. FisCH, New YoRK EvidenCe § 756, at 446 (2d ed. 1977). 


\section{A. General Hearsay Notions}

Before examining any hearsay exceptions, it is necessary to establish soine basic propositions about the hearsay doctrine. While no definition is universally accepted, federal rule 801 (c) is as good as any and takes on additional importance as states codify their evidence rules. ${ }^{82}$ " 'Hearsay' is a statement other than one made by the declarant while testifying at the trial or hearing, offered in evidence to prove the truth of the matter asserted." 83

To have hearsay, not only must a declarant make an utterance (or undertake an action imtended as an assertion) that reflects the declarant's belief, but the assertion must also be offered to prove that the behief held by the declarant reflects reality. Although hearsay statements often are not made under oath and, putting videotape aside, are made under conditions that inake it impossible for the trier of fact to assess demeanor at the time a statement is made, these characteristics are not principally responsible for the general ban on hearsay evidence. Rather, it is the absence of cross-examniation of a statement when it is made that leads to our distrust of hearsay. There are two probleins associated with trusting in the declarant's belief: ambiguity and imsincerity in nraking statements that carmot be tested by cross-examination. Likewise, there are two problems associated with relying on the declarant's observations: faulty memory and inaccurate perception. ${ }^{84}$ Only when the four probleins coexist is a statement defined as hearsay. In other words, the adjudicator should exclude as hearsay a statement that is offered only for its truth. If the statement is otherwise relevant-that is, it is relevant irrespective of its truth-then it is admissible for a nonhearsay purpose.

An example will illustrate the point: Declarant $(D)$ says, "I have a horrible fever. Red splotches cover my body. My sickness threatens any with whom I come im contact." If $D$ made this statement to an innkeeper, whose duty is to serve the public without invidious discrimination, and if the innkeeper turned $D$ away on the ground that she did not wish to expose other guests to a possibly contagious disease, the innkeeper can admit $D$ 's statement concerning $D$ 's condition in her own defense in any subsequent action by the healed $D$ or the local department of huinan resources. The statement is relevant because it was niade and the innkeeper reacted to it. There is no need to go be-

82. See S. SAltzburg \& K. RedDEN, supra note 9, at 791-92.

83. FED. R. EvID. 801(c).

84. Professor Laurence Tribe has offered a useful device, the testimonial triangle, for examining and understanding this hearsay definition. Tribe, Triangulating Hearsay, 87 HARV. L. REv. 957 (1974). The following figure represents a modification of Tribe's triangle; it is designed to depict the hearsay definition as clearly as possible: 
yond the making of the statement to show its relevance. ${ }^{85}$

If $D$ is charged with desertion of family, and a good faith belief that one has a contagious disease is a defense, $D$ 's statement can be introduced in her own behalf as evidence of a good faith belief. Offered for this purpose, it is not hearsay. The statement is relevant to show the declarant's belief, and depends only on the fact of its utter-

B. Belief (Of actor responsible for $\mathrm{A}$ )

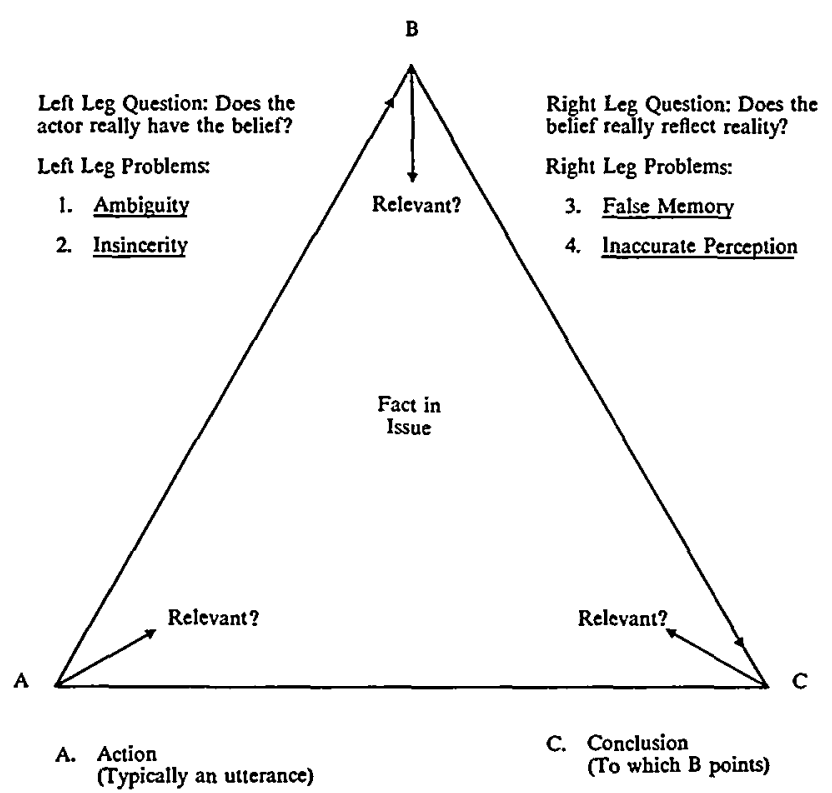

R. Lempert \& S. SAltzburg, supra note 8, at 333 (modified).

True hearsay, as identified in the test above, is a statement that requires the factfinder to move from $A$ through $B$ to $C$ in order to find that the statement is relevant evidence. If the factfinder need only move from $A$ to $B$ or can rely on the fact of utterance alone $(A)$, then the statement is not hearsay.

A linear analysis, such as the following, is also helpful and may be clearer than Tribe's triangle:

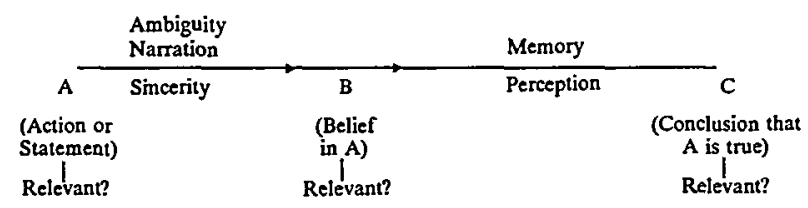

This might be called "Straightening out Hearsay." The linear diagram has several advantages. It makes it clear that one cannot go from $A$ to $C$ without passing through $B$ and that one must reach $C$ to find that a stateinent is hearsay. Thus, when the words of an oral contract are important, testimony about an out-of-court declaration is admissible because there is no need to leave $A$, the actual utterance of the words, to decide that the evidence is relevant. And if the words are circumstantial evidence of something other than their truth, it is not necessary to go beyond A or B. Finally, the linear diagram shows that if one travels from $A$ through $B$ to a conclusion not asserted by the declarant, some of the traditional hearsay problems still exist even though modern codes would not treat such a statement as hearsay.

85. Using either diagrain, note 84 supra, the factfinder would not have to leave $A$ to find that the statement was relevant. 
ance; it is not used to show that it is true. ${ }^{86}$ Hearsay dangers undoubtedly exist, however: $D$ may be fabricating her condition, and the statement is not tested by oath, a jury's assessment of demeanor, or cross-examination. Nonetheless, the statement is nonhearsay virtually everywhere. ${ }^{87}$ The statement could be treated as hearsay if analyzed as the equivalent of the assertion "I beheve that I have a fever," and hence would fall within the definition of hearsay because it would be offered to prove the truth of what was said. But the declarant need not have intended to communicate her state of mind at the time she spoke, and if she did not, memory and perception problems are minimized.

Another variation of the theine not only illustrates a third possible use of the statement and true hearsay, but also leads into the next part of this section. If $D$ brings an action for negligence, breacls of warranty, and strict liability against the manufacturer of a product that $D$ claims caused her to suffer blotching, fever, and associated sensations, $D$ 's out-of-court statement about her condition is relevant only to prove that the imjuries were actually suffered and therefore would be classic hearsay. ${ }^{88}$ Only in this circumstance is it necessary to look to a hearsay exception.

\section{B. Applying Negative Inference Analysis to Hearsay Exceptions}

Statements that are relevant only to show the truth of the assertion made should be admissible in certam situations. Negative inference analysis is a useful tool for ascertaming some of these. Rulemakers can isolate the classes of evidence that factfinders will expect to hear. Before statements that fall into one of these classes are excluded as hearsay, the unreliability of the statements must be balanced against the prejudice to one party created by the negative inferences that a factfinder is likely to draw from the absence of the evidence, as well as against the other factors favoring admission. Hearsay exceptions are

86. The factfinder need only go from A to B to admit the evidence. See note 84 supra.

87. The reason, which may seem arbitrary to some people, is not difficult to divine. Hearsay statements, by definition, involve all four potential problems set out above. When a class of statements is characterized as presenting less than all four problems-e.g., in this hypothetical case where only two of the dangers exist-it is possible to assume that the totality of the danger associated with the evidence is less than the mimimum danger necessary to trigger the application of the hearsay rule. It would be rational, of course, to establish a system that presumed inadmissibility, subject to exceptions, when one, two, or three of the problems is or are present. Whatever choice is made reflects a balance between the benefits of factinding aceuracy and perceptions of fairness attributable to exclusion of out-of-court statements and the costs of barring evidence, measured by the increased errors resulting from exclusion of "good" evidence and the direct costs of hearing and ruling on objections. Simce any trends that can be identified, see R. LEMPERT \& S. SALTZBURG, supra note 8, at 474-89, are in the direction of hiberalizing adinission of evidence, the current balance is generally viewed as excluding sufficient evidence through hearsay rules.

88. In terms of the diagrams, note 84 supra, the utterance is relevant only to show that the statement is true. In other words, the factfinder would have to go the length of the line from $A$ through $B$ to $C$ in order to use the evidence. 
often justified by either the reliability or the necessity for admission of statements falling within the exceptions, or both. These justifications are not always completely convincing. But a recognition of the effect of negative inferences fully supports several of the accepted liearsay exceptions and strengthens the arguments in favor of others.

\section{Statements of Physical or Mental Condition}

In the tort action for personal injury outlined above, two hearsay exceptions apply to $D$ 's utterances: the exceptions for statements of plysical or mental condition. Typical definitions of both are found in the Federal Rules of Evidence. Rule 803(3) provides:

A statement of the declarant's then existing state of mind, emotion, sensation, or physical condition (such as intent, plan, motive, design, mental feeling, pain, and bodily health), but not including a statement of memory or belief to prove the fact remembered or believed unless it relates to the execution, revocation, identification, or terms of declarant's will [is not excluded by the hearsay rule].

Rule 803(4) overlaps slightly; ${ }^{89}$ it provides:

Statements made for purposes of medical diagnosis or treatment and describing inedical history, or past or present symptoms, pain, or sensations, or the inception or general character of the cause or external source thereof insofar as reasonably pertinent to diagnosis or treatment [are not excluded by the hearsay rule].

Stateinents of "present" nrental, eniotional, or physical condition, sucli as those covered by the federal rule, are aniong the most common declarations qualifying as exceptions to the learsay rule. ${ }^{90}$ A declarant who describes a present plyysical sensation or emotional condition or who expresses a present inclination to do sonething in the future is making statenients which, if offered at trial, will be accepted despite a liearsay objection. Standing in sharp contrast are statements of "past"

89. It is apparent that any statement of present physical condition made to a doctor is covered by both hearsay exceptions. The overlap is explained by the different treatment accorded statements made generally and statements made to physicians in some common law jurisdictions. It is unimportant under the Federal Rules of Evidence which exception is used, except insofar as it is difficult to separate present condition from medical history-im which case FED. R. EvID. 803(4) is more useful.

90. One geueral explanation for the exception for statements of personal condition made to anyone is that they are as rehable as other present sense impressions permitted under FED. $R$. Evid. 803(1). Of course, many jurisdictions do not recognize the 803(1) exception, see $R$. LEMPERT \& S. SALTZBURG, supra note 8, at 409. More importantly, one check on ordimary present sense impressions is that "the statement will usually have been made to a third person (the witness who subsequently testifies to it) who, being present at the time and scene of the observation, will usually have an opportunity to observe the situation himself and thus provide a check on the accuracy of the declarant's statement." C. MCCoRMiCK, supra note 11, § 298, at 710 . In most personal condition situations, there is no check on the declarant. When justifications are offered for a broadcr hearsay exception for statements made to a doctor, the possible check against error provided by the nondeclarant medical witness is important. See text accompanying note 116 infra. 
mental, emotional, or plysical condition.91 ${ }^{9 x c e p t ~ i n ~ l i m i t e d ~ s i t u a-~}$ tions, ${ }^{92}$ retrospective statements that describe historical conditions or sensations cannot escape exclusion under the hearsay rule.

Several rationales liave been suggested for receiving as evidence statements of present plrysical or inental condition. While they are somewhat persuasive, they are not fully satisfying. The first, and most commonly offered, is that spontaneity produces reliability. ${ }^{93}$ In hearsay lore, spontaneity is said to protect against fabrication, ${ }^{94}$ although there are heretics." But "[u]nder the federal rule and in most courts the mere concurrence of the statement and the condition described provides sufficient evidence of spontaneity unless the particular circumstances surrounding the statement suggest that the declarant was trying to manufacture evidence in his favor."96 Thus, not every case under the exception actually involves spontaneous speech. Declarations of present pliysical or inental condition can be elaborate, considered, and even preplanned, and are not necessarily innulsive statements. ${ }^{97}$ Other liearsay exceptions admit declarations consisting "of inarticulate groans or screams" ${ }^{98}$ and other clearly spontaneous communications. Inarticulate expressions are considered conduct and thus are not liearsay under 1nodern codes. ${ }^{99}$ Under other codes, the liearsay exception for excited utterances is broad enough to encoinpass stateinents for whicli the evi-

91. Note how the dichotomy between contemporaneous statements and retrospective statements is emphasized by rule 803 (3) but not by rule 803 (4). The reason for the different treatment in the two rules is discussed in the text accompanyimg note 118 infra.

92. Examples are found in the final portion of FED. R. EvID. 803(3) relating to wills and im FED. R. Evid. 803(4) relating to diagnosis or treatment by a physician.

93. See D. Loulsell, J. KAPLAN \& J. WALTZ, supra note 1, at 248. See also E. MoraAN, Basic Problems of Evidence 329 (1962); 4 J. Weinstein \& M. Beroer, supra note 19, at ๆ] 803(3).

94. See, e.g., the excited utterance exception to the hearsay rule. FED. R. Evid. 803(2).

95. See, e.g., Hutchins \& Slesinger, Some Observations on the Law of Evidence, 28 CoLuM. L. REV. 432 (1928).

96. R. Lempert \& S. SAltzbuRG, supra note 8, at 404.

97. Some courts are especially worried about statements made after litigation commences. See R. Lempert \& S. SAltzburg, supra note 8, at 404-05. But most appear to agree with C. MCCORM1CK, supra note $11, \$ 291$, at 685 , that a sufficiently large number of statements covered by the exception are reliable, so that it is better to admit them as evidence even though "some statements describing present symptoms or the like are probably not spontaneous but rather calculated misstatements." The McCormick treatise makes the argument for admission appear stronger than it really is. Hearsay rules are concerned with understatements, overstatemcnts, and degrees of accuracy-the kinds of things cross-examination can explore-every bit as much as deliberate falsification. Moreover, "spontaneity," as the word is used by the treatise, ineludes all statements other than calculated misstatements. If the ineaning of the word is not restricted to unplanned statements prompted by special circumstances, the spontaneity of a statement signifies little about its reliability.

98. B. Witxin, California Evidence $\$ 554$, at 528 (2d ed. 1966) (emphasis in original).

99. See, e.g., FED. R. Evid. 801(a). See also Note, State of Mind: The Illusive Exception, 9 U.C.D. L. REV. 199 (1976). 
dence of spontaneity is most compelling. ${ }^{100}$ The spontaneity argument falters when the physical and mental condition exceptions are applied only to those statements falling exclusively within those exceptions, whicl include rather elaborate descriptions of personal condition. Thus, the exceptions must be justified for reasons other than the simple spontaneity rationale.

A more realistic expression of the spontaneity rationale persuaded the Advisory Committee on the Federal Rules of Evidence: ${ }^{101}$

The strong likelihood of spontaneity is also the basis for the strong need for receiving the declarations. Being spontaneous, they are considered of greater probative value than the present testimony of the declarant, and consequently are admissible despite the availability of the declarant at the time of trial.

Wignore was a bit less cryptic in explaining the need for admission: ${ }^{102}$ [T] here is a fair necessity, for lack of other better evidence, for resorting to a person's own conteinporary stateinents of his inental or physical condition. . . . [S]tatements of this sort on the stand, where there is ainple opportunity for deliberate misrepresentation and sinall ineans for checking it by other evidence or testing it by cross-examination are coinparatively inferior to stateinents inade at times when circuinstances lessened the possible induceinent to misrepresentation.

100. Excited utterances are treated as a hearsay exception in all jurisdictions. See C. McCoRMICK, supra note $11, \$ 297$, at 704 . Such statcinents are adınissible even in jurisdictions that reject the exception for statements of personal condition to lay persons. See E. FISCH, supra note 81, $\S 995$, at $570-71$.

The excited utterance exception has always been controversial. Federal Rule of Evidence 803(2) presents a typical definition of an excited utterance: "A statement relatimg to a startling event or condition made while the declarant was under the stress of excitement caused by the event or condition." It has been argued that however effective excitement is as a guarantor against falsification, it so distorts perception that reliability is a matter of serious concern. See, e.g., Hutchins \& Slesinger, supra note 95 , at 439 . One reason why every jurisdiction recognizes the exception may be that triers of fact expect startled people to inake statements relating to an exciting event. Absence of such statements might cast doubt on whether an event was actually perceived or whether it really was as eventful as courtroom testimony suggests. Introduction of prompt complaints of rape, something that most jurisdictions allow, can be viewed as falling within the scope of the poimt made here. See C. MCCoRMICK, supra note 11, § 297, at 709. See also State v. Cherry, 154 N.J. Super. 157, 381 A.2d 49 (1977) (nale complainant). This is not to suggest that there are no good explanations for a failure to come forward; there surely are. See Berger, Man's Trial, Woman's Tribulation: Rape Cases in the Courtroom, 77 Colum. L. Rev. 1, 5-6 (1977). But it does suggest that courts and juries want to lear the explanations. See, e.g., Willis v. Commonwealth, 218 Va. 560, 238 S.E.2d 811,813 (1977) ("failure to report an alleged rape by force and violence for an unreasonable period after the incident occurred casts suspicion and doubt on the truthfulness of the story . . . unless there is a credible explanation given for such a delay"). Compare Robeson v. State, 39 Md. App. 365, 386 A.2d 795 (1978) and State v. Hairston, - N.C. App. - 244 S.E.2d 448 (1978) (both cases allowing a negative inference from a defendant's failure to provide information to police) with People v. Tate, - Ill. App. 3d -, 379 N.E.2d 693 (1978) (bolding that defendant could give a partial story to police without suffering negative inference). See also J. MAcDonald, RAPE: OFFEndERS AND THEIR Victims 93 (1971).

101. Advisory Committee's Note to FED. R. Evid. 803(3), 56 F.R.D. 183, 305 (1972) (citing C. MCCORMICK, HANDBOOK ON THE LAW OF EvidENCE $\$ \$ 265,268$ (lst ed. 1954)).

102. $6 \mathrm{~J}$. Wigmore, Evidence $\$ 1714$, at 58 (3d ed. 1940). 
These arguments suffer from the same weakness as the simple spontaneity analysis. It is unclear why "spontaneous" statements are so necessary and so much more probative than in-court testimony when they can be lengthy and calculated. Cross-examination at trial is in fact an effective check, since any witness who testifies about past or present physical condition must provide details in order to be believed. Court ordered medical examinations ${ }^{103}$ can further lessen the danger of misrepresentation, and impartial inedical experts ${ }^{104}$ can provide some guarantee agamst fraud. More importantly, assuming that all the devices would inadequately prevent calculated imisstatement at trial, the hearsay exception just exacerbates the danger by admitting misstatements inade out of court.

The second rationale, necessity, rests on the need to protect the party against whom proof of a certain physical or mental condition is offered. Even without the exception, however, any out-of-court statement by a party-declarant whose condition is in dispute, that was less favorable to that party-declarant than her m-court testimony, can always be introduced as a party adinission. ${ }^{105}$ In practice, then, the exception usually aids the party claiming the disability by creating an extrajudicial record that may be difficult to examine. Hence, the "need" arguinent flounders about with little to support it.

The third commonly offered rationale is that " $[t]$ he hearsay risks are at a minimuin here. There is no perception problem since the declarant is relating what he feels at the time. There is no inemory problem where the declaration relates to present symptoms."106 This analysis suggests that two of the problems associated with hearsay are removed. But as Professor Tribe has noted, "if the sensation mvolved is sufficiently coinplex or has a sufficiently unconscious component it remains possible for the person reporting the sensation to be the victim, of false perception or false 'self-knowledge.' "107 Thus, he correctly concludes that the accuracy of the declarant's perception can not always be trusted. ${ }^{108}$ Not only is the declarant's perception itself unreliable, but inadequate attention and concern may also have distorted the deciarant's observations.

It is debatable whether the three rationales standing alone are sufficient to support the exceptions for declarations of present physical or mental condition. But one additional argument enhances the case

103. See generally FED. R. Civ. P. 35.

104. See generally FED. R. Evid. 706.

105. At common law this was an exception to the hearsay rule. Under FED. R. Evid. 801(d)(2), admissions are exempted from the definition of hearsay.

106. D. Louisell, J. KAPLAN \& J. WALTZ, supra note 1, at 248.

107. Tribe, supra note 84 , at 965 n. 25 .

108. Discussimg the point in terms of his triangular model, Tribe noted that "it is not entirely accurate to describe such statements as mvolving no right-leg infirmities." Id. 
for admission of this evidence: triers of fact, especially juries, often expect such evidence to exist in cases where it is relevant and often will draw negative inferences from its absence. ${ }^{109}$

Fidelity Service Insurance Co. v. Jones ${ }^{110}$ illustrates the point. An insured died in a bathtub accident in his father-in-law's home. Plaintiff, father of the deceased, claimed under an insurance policy that protected against death by drowning unrelated to a disease or infirmity. There were two theories of how the death occurred: (1) that the deceased fell, struck his head, and drowned; or (2) that he blacked out, fell and drowned. Defendant insurance company objected to plaintiff's eliciting of testimony that the deceased never complained of being sick or not feeling well. The Alabama Supreme Court held that the trial judge properly admitted the evidence. Because no one could reconstruct the precise nature of the accident, the jury was forced to speculate on whether death was purely accidental or the result of a diseaserelated accident. Since the jury would consider the possibility of a blackout, it was essential for the plaintiff to show that any blackout was not due to disease or infirmity. The absence of complamts was relevant to show the deceased's good health and thus reduced the probability that the deceased had blacked out. ${ }^{11}$ A jury can reasonably expect that the persons closest to the deceased would have information about his condition; any failure to produce such imformation might cause the jury to draw negative inferences against the plaintiff. The exclusion of the testimony would protect the defendant from the unreliability of out-of-court statements, or here, out-of-court silence, but the plamtiff would suffer doubly-from the mability to strengthen the case with the evidence and from the jury drawing a damaging and maccurate conclusion from the absence of the evidence. Thus, Fidelity Insurance illustrates that, even in the less familiar case in which out-of-court silence is offered as evidence, the negative inference analysis is helpful. Its utility is more readily apparent in the more familiar case when a plaintiff offers evidence, not of silence, but of out-of-court complaints of physical or mental sufferimg.

If the person whose condition is at issue is unavailable, the analy-

109. The argument in no way suggests that juror expectations provide the sole or even the predominant justification for the hearsay exception, but only that the case for the exception is strengthened when an additional reason is offered. Elsewhere $I$ have noted that pigeonholing evidence arguments so that every rule has one rationale and/or one purpose is a mistake. "Technical rules of competency [like hearsay] serve numerous purposes," Saltzburg, supra note 67, at 275 , and several rationales can be offered for various rules. See, e.g., id. at 271-72 n.2.

110. 280 Ala. 195, 191 So.2d 20 (1966).

111. The deceased's actious might substitute for verbal complaints, but often actions are less useful than speech as a means of describing sensations experienced by the human body. Of course, absence of complaint would fall outside the definition of hearsay under FED. R. EvID. 801. But see FED. R. Evid. 803(7) \& (10). A difficult relevance problem would exist for inany courts. See C. MCCORMICK, supra note 11, at 476-77. 
sis in the case of the out-of-court complaint is similiar to that developed in connection with extrajudicial silence. The danger is that exclusion of evidence of complaints may deprive the party attempting to prove an mjury of relevant evidence and cause the jury to assume that there were no prior complaints and probably no mjury. Even when the person whose physical or mental condition is at issue is available to testify, the factfinder still might draw a negative inference if that party offers no evidence of prior complamts or if an adverse party brings up the fact that no out-of-court complamts were proved. A helpful hypothetical was presented in a videotape exercise for trial judges prepared by the American Academy of Judicial Education. ${ }^{112}$ In a neghigence case arising out of an automobile accident, the following exammation takes place after the presentation of in-court testimony about plaimtiff's imjuries:

Defense Attorney calls Mr. Black: Have you been with Mr. Jacobs, the Plaintiff, periodically since the accident?

Mr. Black: Yes, we are on the same bowling team and I have been with him every Tuesday might since 1970.

Defense Attorney: Simce the accident, has he ever said anything to you concerning pain or discomfort in his neck or back?

Mr. Black: No, he has never complaimed.

If it is true that juries expect to hear evidence of complaints from someone suffering neck and back mjuries, and that juries would expect someone who is not really injured not to complam, the exclusion of this evidence denies the defendant an opportunity of satisfymg jury expectations. ${ }^{113}$ Without this evidence, the jury may still penalize the plaintiff for failing to produce evidence of complaimts, but positive evidence is more persuasive than necessarily speculative negative inferences, and the admission of the evidence brings the issue into the open where both sides can address it. Likewise, if the plaintiff offers evidence of past complaints, the failure to adimt the evidence may cause jurors unfairly to penalize the plaintiff for disappointing their expectations-a real possibility if the jury learns that the plamtiff had engaged in a physical activity like bowling. ${ }^{114}$

Statenients of present physical and mental conditions are the kind of evidence that a jury will expect to hear. Thus, negative inference analysis leads to the conclusion that this class of statements should be excepted from the hearsay ban. The commonly advanced justifications

112. See also R. Jones, Relevancy: A Discussion Guide, objection 37 (Am. Acad. Jud. Educ. 1976).

113. Once again the absence of complaints would not be hearsay under FED. R. Evid. 801 . See note 111 supra. Relevance problems would remaim for many courts.

114. This penalty may be exacted whether or not the person whose condition is relevant is available to testify. Thus, unavailability requirements, which exist in some jurisdictions, see $D$. Louisell, J. KAPLAN \& J. WALTZ, supra note 1, at 249, are probably unwise. 
for the hearsay exceptions for such statements are not completely convincing. But the exceptions are fully justified when one adds the cumulative probative value of such statements - that is, their persuasiveness as positive evidence and the increased accuracy of jury "speculation" gained by not excluding them-to their relative reliability. Under certain circuunstances, the adjudicator can counteract the influence of negative inferences with a jury instruction to disregard whether any out-ofcourt statements were made, especially when the injured party testifies. Thus, in soine cases, balancing rulings under rule 403 may lead the adjudicator to decide to reject the evidence on a relevance and balancing analysis. If, however, we favor the development of a complete evidentiary record in modern trials without questionable technical restraints, we must admit evidence of statements of present inental or physical condition, or the lack thereof, in most cases in which such stateinents are relevant.

\section{Statements of Past Condition Made to Physicians}

Statements of present physical or mental conditions made to physicans are, like similar statements inade to others, generally admissible despite a hearsay objection. In addition to the arguments supporting the admission of statements of present conditions made to laypersons, there are particular reasons to trust these statements when inade to a doctor. ${ }^{115}$

If the declarant knows that the physician is going to treat him, he is unlikely to give the physician dehiberately incorrect information; the joke would prove to be on the patient. Furthermore, the patient is likely to beheve that the physician knows a great deal about physical conditions. It is arguable, therefore, that the patient will not supply false data since the physician will only discover its falsity after possibly painful and costly tests. Finally, the physician's expertise is available to corroborate the accuracy of the out-of-court declarant's statements concerning his physical condition. ${ }^{116}$

Statements of past condition have traditionally been treated as unexcepted hearsay. ${ }^{117}$ They lack even the superficial spontaneity that justifies the admission of statements about present conditions. Furtherinore, their exclusion does not prejudice either party, because the jury

115. Arguably, many statements to physicians are less spontaneous because the declarant may have deliberated whether or not to see a doctor and pondered what to say. Also, the doctor may control the discussion more than the average layperson would. Sometimes the doctor even may suggest ideas to the declarant. Too often, however, these problems are ignored. See, e.g., Commissioner's Note to UNIform RULE OF Evidence 63(12) (1953). But see C. MCCormicK, supra note $11, \S 292$, at 690 .

116. D. Louisell, J. KAPLAN \& J. WaLTZ, supra note 1, at 248.

117. Statements of present conditions made to a treating physician are everywhere admissible. "There is scarcely any dissent from this rule . . ." 2 B. JONES, EvidENCE $\$ 10: 7$, at 270 (6th ed. S. Gard 1972). 
is unlikely to expect someone to relate past medical history im most circumstances. ${ }^{118}$ Although most jurisdictions have barred the use of statements of past condition-that is, medical history-made by a patient to a physician, the Federal Rules of Evidence and a growing number of states ${ }^{19}$ allow the jury to hear evidence of such stateinents made by a patient receiving treatment. ${ }^{120}$

Most jurisdictions that have excepted statements of past medical history from the hearsay rule have done so in reliance on the patient's self-interest im truthfully reporting to a diagnosing physician. A patient's interest in developing a case may outweigh any danger of faulty diagnosis, however. Some patients will know that there are inedical problems that are difficult to verify, those probleins that either cannot be treated or that can be treated without causing the patient pain. They may also choose physicians known not to question patients closely or to look for possible falsification. Some physicians may have a financial incentive not to challenge their patients. (Moreover, rules like federal rule 803(4) extend to diagnosing physicans who will perform no treatinent, an extension considered below.) Despite these objections, there are other reasons supporting the exception which, when added to the increased likelihood of accuracy engendered by the doctor-patient relationship, justify it.

In practice, most jurisdictions ${ }^{121}$ would admit the evidence under another approach: a physician giving an expert opmion may testify about "the history of an mjury or illness given to him by the patient for the purpose of diagnosis or treatment of such mjury or illness whether the statement relates to the conditions or symptoms existing at the time, or to past symptoms or conditions relevant to the condition being treated" in order to provide a basis for the opimion. ${ }^{122}$ In other words, a doctor who cannot testify that her patient said, "My back has hurt me for three years," to prove that the patient actually suffered, inay testify

118. In cases in which no statements of present condition are made, only statements of past feelings or condition, introduction of the retrospective statements arguably would help to meet juror expectations. While the argument has some merit, its strength is outwcighed by three factors: first, the jury expects that persons in pain or possessing strong feelings will so indicate while the condition exists and retrospective statements do not satisfy the expectation; second, opportunities to manufacture evidence, although they presently exist without much restriction, undoubtedly would be multiplied; and third, the additional problem of faulty memory (a right leg of the triangle problem, see note 84 supra) must be added to the balance.

119. See, eg., E. Morgan, Basic Problems of Evidence 330 (1962).

120. Yet "[m]ost courts . . . will exclude declarations about past bodily condition as proof of the existence of that condition." D. Loulsell, J. KAPLAN \& J. WALTZ, supra note 1, at 249. There are memory problems with retrospective statements, but the modern trend is to minimize the faulty memory problems.

121. See R. Lempert \& S. SAltzburg, supra note 8, at 406.

122. See D. Louisell, J. Kaplan \& J. Waltz, supra note 1, at 249. 
that the patient made the statement so that the doctor can explam her diagnosis.

It is somewhat ironic that evidence that is not admissible for its truth is admissible for another purpose when the jury will probably use it for its truth despite any limiting imstruction. ${ }^{123}$ A better solution may be to exclude the evidence totally rather than to admit it with no practical restriction on its use. ${ }^{124}$ As this Article has emphasized, however, evidence should not be admitted or excluded without some consideration of its effect on jury expectations. Jurors would expect a patient to reveal her condition to a treating physician and might assume that the absence of evidence supports the conclusion that there was no condition to complain about. It is unlikely that any instruction designed to prevent this conclusion would be effective. On balance, the danger of prejudice to the party whose evidence is excluded supports the exception despite the possibility of falsification.

The same considerations justify extending the exception to include stateinents made to diagnosimg physicians as well as to treatimg physicians under Federal Rule of Evidence 803(4), a dramatic departure from previous codes. ${ }^{125}$ The dangers of falsification are inagnified when doctors are consultcd solely to testify about their diagnoses, because the patient's ouly interest is in extracting a diagnosis favorable to her case. ${ }^{126}$ As with statements to treating physicians, most jurisdictions nonetheless allow the introduction of the evidence to show the basis of a doctor's diagnosis. Here again, a major factor is the jury's reaction both to the admission of the evidence, which would be subject to cross-examination and jury scrutimy, and its absence, which would give rise to unchecked speculation. The dangers of exclusion far outweigh those of admission, and therefore, negative inference analysis, when added to the closely balanced traditional arguments, justifies this expansion of the hearsay exception to include statements of past physical or mental condition made to physicians.

123. See 2 B. JONES, supra note $117, \S 10: 7$, at 271 .

124. Hypothetical questions could be asked, for example. And physicians could testify to objective facts not dependent on communications from their patients, as physicians consulted to obtain trial testimony now do in some jurisdictions. See D. Louisfil, J. Kaplan \& J. WaLtZ, supra note 1 , at 249-50.

125. See C. McCormick, supra note 11, § 293, at 692-93; 4 J. WeINSTEIN \& M. Berger, supra note 19, If 803(4) [01], at 125.

126. Because the jury should only expect that a patient would disclose information that is relevant to the purpose for which medical consultation is sought, it makes sense to limit the exception to statements describing "the cause or external source" of a condition "imsofar as reasonably pertinent to diagnosis or treatment." FED. R. EvID. 803(4). Statements about causation are less spontaneous, less personal, nuore dependent on memory and more likely to be self-serving than other statements we have discussed. Insofar as they are needed by the doctor for medical treatment, the reliability arguments made previously and negative inference analysis justify an exception, though niost courts are hestitant to include statements about causation in the hearsay exception. See C. MCCormick, supra note 11, § 292, at 691-92. 


\section{Present Declarations of Intention: The Hillmon Doctrine}

One of the most notorious exceptions to the hearsay doctrine is that which permits the imtroduction into evidence of statements of present imtent to act in the future. ${ }^{127}$ As one commentary has aptly noted, "[t] $]$ he starting point for all discussions of statements of intention to prove a subsequent act is Mutual Life Insurance Co. v. Hillmon ...."128 Not only is Hillmon an important case in the law of evidence, but it is a fascinating piece of American history.

In Lawrence, Kansas, in 1878 John W. Hillmon, "a solnetime soldier, miner, hunter, and cowboy," ${ }^{129}$ was a cattle herder without visible ineans of support. In the fall, he married Sally Quinn, a cousin of Levi Baldwin, a wealthy cattleman. Baldwim offered to buy the couple a ranch in the Southwest for which Hillmon was to search. Hillmon took out three life insurance policies, apparently to protect his wife in case he died during the trip. At the time, the Southwest was still primitive and heavily populated with Indians. On March 1, 1879, Hillmon left Lawrence for Wichita and the Southwest in the company of John H. Brown. On March 17, Hillmon was allegedly killed at a campfire on Crooked Creek when a gun that Brown was puttimg in a wagon accidentally fired. Sally Quinn Hillmon filed a claim for the proceeds with the three imsurers, who refused to pay. ${ }^{130}$

The only eyewitness to the shootimg was Brown, who first claimed to have accidentally shot Hillmon. At a coroner's inquest, in which extensive medical testimony was accepted and the identification of the body intensely disputed, the inquest jury found that Brown feloniously shot an unknown man. On the advice of his counsel (retamed by the insurers), Brown turned state's evidence and confessed to participation

127. See, e.g., UNIFORM RulE OF EvidenCE 63(12)(b) (1953, superceded 1974). That FED, R. EviD. 803(3) covers such statements is clear from the parenthetical inclusion of the word "intent" in the text of the rule and from the legislative history. See S. SALtzburg \& K. REDden, supra note 9, at 529,541, 558. The drafters of the rule eliminated the language of Uniform Rule of Evidence 63(12)(a) - "when such a mental or physical condition is in issue or is relevant to prove or explain acts or conduct of the declarant"-apparently because the coinmittee preferred to enphasize that the question "whether the inference from intent to act inay be drawn is a matter of relevancy rather than a concern of the hearsay rule." $4 \mathrm{~J}$. WEINSTEIN \& M. BERGER, supra note 19, If 803(3)[04], at 101-02.

128. 4 J. WEINSTEIN \& M. BERGER, supra note 19, I 803(3) [04], at 102 (footnote omitted) (refcrring to 145 U.S. 285 (1892)).

129. Id.

130. The refusal was based on several pieces of information: (1) There had been three recent schemes in Kansas where insureds faked death for insurance money. (2) Baldwin and Hillmon had actively secured the policies themselves, which was considered highly unusual. (3) In late 1878, Baldwin had come upon hard times and was liard pressed by his creditors. (4) In the fall of 1878, Baldwin had allegedly asked a doctor how long it would take for a dead body to decompose and had askcd him whether it might be "a good scheme to get insurcd for all you can, and get someone to rcpresent you as dead, and then skip out for Africa or some other damn place." MacCracken, The Case of the Anonymous Corpse, AM. Her., June 1968, at 51-52. 
in a conspiracy with Hillmon and Baldwin to defraud the insurers. The insurers also learned that an Iowa family had been sending out inquiries about their son who had suddenly stopped writing home after heading to Kansas. His letters once had been steady and regular. On March 1, 1879 he had written his sister, "I intend leaving Wichita on or about March 5th, with a certain Mr. Hillmon . . . for Colorado and parts unknown to ine." On March 1, he had written his sweetheart that he had taken a job with a Mr. Hillmon and would be leaving soon for Kansas, Indian Territory, Colorado, and New Mexico. The family's inquiries reached Lawrence and someone sent them photos of the corpse which they immediately identified as their son, Frederick Walters.

After twenty-five years of litigation that included six trials ${ }^{131}$ and two trips to the United States Supreine Court, ${ }^{132}$ only part of the case was resolved, and it appears that settlements with two of the insurers ended the case before the seventh trial took place. ${ }^{133}$

Walters' letters were important evidence for the insurance company. After they were admitted in the first two trials, they were excluded in the third, and the plaintiff, Sally Hillmon, prevailed temporarily prevailed that is, because the Umited States Supreme Court reversed the judgment on the ground that the letters should have been admitted. Justice Gray, writing for the Court, stated:

The existence of a particular intention in a certain person at a certain time being a inaterial fact to be proved, evidence that he expressed that intention at that time is as direct evidence of the fact, as his own testimony that he then had that intention would be. After his death, there can hardly be any other way of proving it; and while he is still alive, his own memory of his state of mind at a former time is no more likely to be clear and true than a bystander's recollection of what he then said, and is less trustworthy than letters written by him at the very time and under circumstances precluding a suspicion of misrepresentation.

The letters in question were competent, not as narratives of facts cominunicated to the writer by others, nor yet as proof that he actually went away from Wichita, but as evidence that, shortly before the time when other evidence tended to show that he went away, he had the intention of going, and of going with Hillmon, which made it more probable both that he did go and that he went with Hillmon, than if there had been no proof of such intention. ${ }^{134}$

131. The results are outlined in J. Maguire, J. Weinstein, J. Chadbourn \& J. Mansfield, Cases and Materials on Evidence 715-16 (6th ed. 1973).

132. In addition to the opinion described in the text, see Connecticut Life Ins. Co. v. Hillmon, 188 U.S. 208 (1902).

133. See MacCracken, supra note 129 , at 77 . Sally Hillmon received a total of $\$ 35,000$, including interest, from the insurers.

134. 145 U.S. at 295-96. 
Putting aside for the moment the propriety of using one person's declarations to prove the subsequent acts of another, ${ }^{135}$ and focusing on the use of statements of future intent to prove the declarant's own subsequent actions, it is apparent that Justice Gray's opinion is more confusing than illuminating. His reasoning had two related parts: First, if a person's intention is a material issue, his declarations about that intention should be admitted because this evidence is better than testimomal evidence which is dependent on the declarant's memory. Second, if the declarant is unavailable, the declarations are the only available evidence and, thus, especially necessary.

Contrary to Justice Gray's suggestion, Walters' intention was not itself the material issue in Hillmon. ${ }^{136}$ But it was relevant because it was circumstantial evidence bearing on whether he went to Crooked Creek and was killed there, as Justice Gray recognized in the second paragraph. Despite the inconsistency, the Court's result makes sense. It found that the exception for present mental condition includes present hopes, present desires, and present intentions. As long as Walters' letters were relevant, the saine rationale for admission of laypersons' statements about present mental condition to others justified the admission of the letters. The letters were indeed relevant because the existence of an intention to do something makes it somewhat more likely that the intended event occurred.

The probative value of the letters was actually greater than the Court recognized. The hearsay exception for statements of present intention to act in the future, like the exception for statements of past condition made to a treating physician, is open to question, but would be less so if a negative inference analysis were apphed. In Hillmon itself, the opinion would have been more convincing if the Court had considered the possibility of the factfinder drawing a negative inference from the absence of proof that Walters intended to travel. In other words, identification of the corpse, particularly by parents who might be presumed to have been kept aware of their son's moveinents, might be suspicious without evidence of Walters' intention to go to Crooked Creek. The negative inference would have been inore powerful at a time when travel was difficult and dangerous. Elsewhere, it has been noted that "[i]t is a nnatter of everyday experience that a inan leaving his hoine, or his business establishment, for an out-of-town trip will, for doinestic and business purposes, inform his family or business associates as to his destination, traveling companion, purpose and anticipated

135. See text accompanying notes $140-49$ infra.

136. In contrast, if a present intention to do something in the future is itself relevant-e.g., if domicile is judged by a present intention to remain indefinitely in a place-then the disputed issue would be identical to the intention of the declarant. 
time of return." 137 In many cases jurors will expect evidence of intention, and denying them that evidence might disappoint their expectations and unfairly hurt one party. ${ }^{138}$ This reasoning alone justifies the Hillmon result. ${ }^{139}$

\section{Statements of Intent Used to Show the Intent of Another}

This section addresses the portion of Hillmon previously put aside-whether one person's declaration should be admitted to prove what another person subsequently did. In Hillmon, the Court's statement that Walters' letters could be admitted not only to show that Walters went to Crooked Creek but also to show "that he went with Hillmon" is little more than dictum. In offering the letters, the insurance company sought to prove that Walters went to Crooked Creek and died there, and that the body found there was Walters'. Even if Walters did not go with Hillmon the insurance company would have had a defense. There was other evidence that Hillmon went to Crooked Creek; indeed, his wife needed to prove this to wim. Thus, neither party disputed whether Hillmon went. The sole question was

137. State v. Vestal, 278 N.C. $561,582-83$, 180 S.E. 2 d 755,769 (1971). The negative inference theme developed im this Article would be consistent with the rejection of particular types of statements of intent on the ground that they are highly unreliable predictors of behavior-e.g., threats to kill someone. See Hinton, States of Mind and the Hearsay Rule, 1 U. CHI. L. REv. 394 (1934); Hutchins \& Slesinger, supra note 95 . Arguably, a jury would assume that few persons actually planning to kill someone would admit it in advance. Some recent opinions confine the Hillmon rule to statements made at or about the time of an act of departure. See, e.g., Fite v. Ammco Tools, lnc., 199 Neb. 353, 258 N.W.2d 922 (1977). The negative inference associated with the absence of a statement increases in strength as the focus narrows to the period preceding an alleged departure.

138. Professor Tribe has argued that the Hillmon exception should be conditioned on unavailability: "[W]hen an utterance relates to future events, the best time for cross-exammation is after the future events have (or have not) taken place." Tribe, supra note 84, at 971. Elsewhere I have jomed in arguing that "[i]t is so clear that an individual's in-court testinnony is more probative as to whether a particular action occurred than are his earlier expressions of intent to engage in that action that this aspect of the state of mind exception is typically used only where the declarant is unavailable." R. Lempert \& S. SAlTZBURG, supra note 8, at 413. It now occurs to ine that 1 overlooked the powerful negative effect that disappointed juror expectations have and that the evidence is often important even when the declarant is available. For an argument in favor of the use of state of mind evidence to corroborate in-court testimiony, see Hinton, supra note 137.

139. At the time Hillmon was decided, the negative inference problem was greater than it is today becanse the common law rule treated assertive conduct as hearsay. See Falknor, The Hearsay Rule as a "See-Do" Rule: Evidence of Conduct, 33 RockY MT. L. Rev. 133 (1960); Fimman, Implied Assertions as Hearsay: Some Criticisms of the Uniform Rules of Evidence, 14 STAN. L. REv. 682 (1962). But for the exception under discussion, evidence of nonassertive conduct, as well as declarations, would have been barred, thereby increasing the odds that a negative inference would be drawn. Today nost nonassertive conduct is admissible without rehance on an exception to the hearsay rule. The negative inference problen still exists, but its impact is somewhat diminished. The problein remains, even if one concludes that many persons do not follow up their statements with actions. See Hutchins \& Slesinger, Observations Upon the Law of Evidence, 29 ColuM. L. REv. 147 (1929); Slough, Relevancy Unraveled, 5. KAN. L. REv. 1 (1956). In fact, if people make more assertions about future conduct than are carried through, the expectation that a statement would be tnade in cases in which action is truly contemplated is strengthened. 
whether Walters did also, and the letters were evidence that he did. ${ }^{140}$

The issue is inore clearly presented in People $v$. Alcalde, ${ }^{141}$ in which the jury heard evidence that the murder victim told two persons that she was goimg out with Frank (the defendant's naine) on the night of the murder. The trial judge instructed the jury that the evidence was received for the purpose of showing the victim's imtention. In his dissenting opinion, Justice Traynor argued that because the evidence was "overwhelming as to who the deceased was and where she was when she met her death," 142 no legitimate purpose was served by showing the deceased's intent. "The only purpose that could be served by admitting such declarations would be to induce the behef that the defendant went out with the deceased, took her to the scene of the crime and there murdered her." 143 Justice Traynor viewed this use of the evidence as improper because it amounted to a declaration by the deceased of Frank's intentions, which could only be beheved if the deceased correctly gleaned and interpreted them. All of the hearsay dangers would then have been present.

But a majority of the Cahfornia Supreme Court rejected the Traynor argument. The majority opinion suggests that the statement was not made under circumstances creating a suspicion of untruth, it was relevant, and there was other evidence estabhishing that the defendant and the deceased were together on the night of the murder. A close reading of the court's opinion leaves one with the feeling that any error in the reeeipt of the evidence would have been harmless im light of the far more damagnig and, im fact, overwhelning evidence in the case. ${ }^{144}$ Some have justified the decision on the ground that "common sense suggests that one's belief that she has a date with a romantic attachment on the night of the day the belief exists is more likely than not to be correct." 145 Others have concluded that the majority's view amounts to a dangerous distortion of the Hillmon exception because one inay have good cause to mislead others as to one's plans to do something with someone else and even the best intentioned declarant may be mistaken as to another's plans. ${ }^{146}$ There still is no consensus. ${ }^{147}$

140. If the letters had been used as evidence that Hillmon conspired to murder Walters, a much more difficult problem would have been presented.

141. 24 Cal. 2d 177, 148 P.2d 627 (1944).

142. Id. at 190, 148 P.2d at 633 (Traynor, J., dissenting).

143. Id.

144. I say this as one who would not be quick to find harmless error. See Saltzburg, The Harm of Harmless Error, 59 VA. L. REV. 988 (1973).

145. Seidelson, The State of Mind Exception to the Hearsay Rule, 13 DuQ. L. Rev. 251, 270 n.21 (1974). Accord, R. Lempert \& S. SAltzbuRG, supra note 8, at 414.

146. See, e.g., B. WITKIN, supra note $98, \S 569$, at 543 (diseussing post-Alcalde cases and adopting Justice Traynor's dissenting opmion in Alcalde).

147. It is interesting that the Advisory Committee's Note to FED. R. Evid. 803(3) states that "[t]he rule of Mutual Life Ins. Co. v. Hillmon, . . . allowing evidence of intention as tending to 
As time goes by, it will probably become apparent that the Alcalde dissent had the better of the pure Hillmon argument, although the majority's conclusion that the evidence should have been admitted in that particular case might be deeined the correct result. Because all of the hearsay dangers are present in a setting im which a declarant describes what she and another intend to do, a presumption of inadinissibility harnessed to the acceptance of an ad hoc exception, such as Federal Rules of Evidence 803(24) and 804(b)(5), for cases in which highly probative evidence falls outside traditional hearsay exceptions, makes a good deal of sense. ${ }^{148}$

Assuming that in Alcalde, or in soine other case, the offered evidence presents a close question of admissibility, attention to juror expectations inay tip the balance. ${ }^{149}$ There was evidence in Alcalde that Frank previously had called the deceased's rooming-house to inquire about her. Thus, his relationship with the deceased was known to those persons who testified about the deceased's declared intention to date Frank on the evening of her death. If the deceased had failed to name Frank as her date when she spoke to those close to her, a jury might have found that she probably was not meeting him. If such a negative inference might have been drawn, the case for admission of the evidence is strengthened slightly. In some cases the negative inference could be considerably stronger and the argument for admissibility significantly enhanced.

\section{Retrospective Statements}

The Hillmon doctrine is often considered in connection with Shep-

prove the doing of the act intended, is, of course, left undisturbed." 56 F.R.D. 183, 305 (1972) (citations oinitted). Whether this includes that part of Hillmon referring to statements regarding a third party is unclear, as is the status of that part of the Hillmon opinion itself. See text accompanying note 140 supra. The House Judiciary Committee report on the Federal Rules of Evidence, H.R. REP. No. 93-650, 93rd Cong., Ist Sess. 13-14 (1973) (citations omitted), states that "the Committee intends that the Rule be construed to limit the doctrine of Mutual Life Insurance Co. $v$. Hillmon, . . . so as to render statements of intent by a declarant admissible only to prove his future conduct, not the future conduct of another person." As I have notcd elsewhere, "[i]t should be interesting to see whether this intent is attributed to the full Congress as the case law develops." S. SAltzburG \& K. RedDen, supra note 9, at 529.

148. It is important to distimguish arguably strong cases like Alcalde from cases like People v. Merkouris, 52 Cal. 2d 672, 344 P.2d 1 (1959), cert. denied, 36 I U.S. 943 (1960). The latter case scrves as a reminder that sometimes statements of intent by a victin can be admitted to show a state of mind inconsistent with the activity that the defendant attributes to the victim. See, e.g., United States v. Brown, 490 F.2d 758, 767 (D.C. Cir. 1973). See also People v. Conrad, 31 Cal. App. 3d 308, 107 Cal. Rptr. 421 (2d Dist. 1973), discussed in Note, State of Mind: The Elusive Exception, supra note 99, at 219-22. Also, courts must remeinber that in some cases a victim's declarations may be adinissible, especially if communicated to the defendant, for the nonhearsay purpose of showing that the defendant was on notice of what might be taken as implicit threats. This point is easily overlooked. See, e.g., State v. Butler, 560 P.2d 1136 (Utah 1977).

149. But see note 166 infra. 
ard v. United States, ${ }^{150}$ a case involving declarations about past cvents. The Supreme Court reversed a husband's conviction for the murder of his wife because a nurse was improperly permitted to testify that, after the nurse brought the wife a bottle of whiskey from the defendant's room as the wife requested, the wife inade three statements: she said that this was the liquor sle drank before collapsing; she insisted the smell and taste were strange and asked if enough whiskey were left to test for poison; and she declared, "Dr. Shepard has poisoned me."151

After rejecting the government's other hearsay arguinents, ${ }^{152}$ the Court addressed the Hillmon issue. Justice Cardozo observed that "[t]here are times when a state of mind, if relevant, may be proved by contemporaneous declarations of feeling or intent."153 But the Court drew a firm line between declarations of intention, directed toward the future, and statements from memory, pointing toward the past. Hillmon was reaffirmed as good law, but was described as "the high water line beyond which courts have been unwilling to go."154 In support of its distmction, the Court argued that in retrospective statements "the dangers of improper perception, faulty memory and danger of imsimcerity are far greater" 155 than in statements of future intent.

An examination of the Court's lolding in the light of the possible inferences the jury imight have drawn from the absence of the wife's dying declaration supports its result. A jury would almost certainly view the absence of accusatory statements by the victim of a murder by poison as unsurprising, and therefore would not be unfavorably disposed towards the government's case. ${ }^{156}$ If other evidence is intro-

150. 290 U.S. 96 (1933).

151. Id. at 98.

152. The court of appeals held that this testimony did not qualify as a dying declaration but held that it was admissible to rebut the defense's contentiou that the wife had committed suicide. Shepard v. United States, 62 F.2d 683 (10th Cir. 1933). The latter holding was rejeeted by the Suprene Court because the government had offered the evidence for its truth. The Court's realization that it could hardly be expected that the jury on its own would have limited the use of the evidence produced Justice Cardozo's famous words:

It will not do to say that the jury might accept the declarations for any light that they cast upon the existence of a vital urge, and reject them to the extent that they charged the death to someone else. Discrimination so subtle is a feat beyond the compass of ordinary minds. The reverberating clang of those accusatory words would drown all weaker sounds. It is for ordinary minds, and not for psychoanalysts, that our rules of evidence are framed. . . . When the risk of confusion is so great as to upset the balance of advantage, the evidence goes out.

290 U.S. at 104.

153. 290 U.S. at 104 (citing Hillmon).

154. Id. at 105 .

155. 4 J. WEINSTEIN \& M. BERGER, supra note 19, \ 803(3)[05], at 113. If Shepard had approved the government's theory, "the exception would swallow the hearsay rule, for one would be reasoning from the declarant's behef to the action asserted or imphed by the statement in almost the same way one reasons in the pure hearsay situation." R. LEMPERT \& S. SALTzBURG, supra note 8, at 410 . See also Tribe, supra note 84, at 970-71.

156. Compare this fact situation with that of a dying declaratiou. Although such a declara- 
duced which, in conjunction with the absence of the wife's exclamations, gives rise to damaging negative inferences, the accusatory statements should be admissible, perhaps in a less inflammatory form. For example, in Shepard the Court recognized that evidence of suicide offered by the defense might entitle the government to respond with the wife's statements if the purpose for admitting thein were carefully explamed to the jury.

A possible criticisin of the line between statements of intent and retrospective stateinents is that Hillmon and Shepard combime to admit the less trustworthy evidence and exclude the better evidence, since a statement inade an hour, or a day, after an event occurs inust be inore valuable than a stateinent of an intention to act in the future that inay never be carried out. ${ }^{157}$ The weakness of this criticisin is that it fails to recognize that the drafters of the hearsay rules have managed, inadvertently perhaps, to create other exceptions that admit retrospective evidence in circuinstances when a negative inference might arise from the absence of the evidence. In light of the other recognized hearsay exceptions, the argument would have to be recast as follows if it is to be fairly assessed: A statement is inore useful to the trier of fact than a statement of intent prior to the event when it: (1) is inade so long after the occurrence of an event that it fails to qualify as a present sense impression, ${ }^{158}$ (2) is suffently devoid of surrounding stimuli that it cannot qualify as an excited utterance, ${ }^{159}$ (3) is not recorded as a part of a regularly conducted activity, ${ }^{160}$ and (4) falls outside all the other established hearsay exceptions. ${ }^{161}$

The argument as recast is less compelling than the more simphistic original version. Statements reporting past events suffer froin the lapses in the declarant's inemory which follow quickly after the event, ${ }^{162}$ and usually the lack of evidence of a person's statements after the excitement of an event has passed would not disappoint juror expectations. Therefore, in inost cases, retrospective statements are properly excluded. Nonetheless, there nay be some cases in which a

tion would be admissible if made, the trauma of impending death makes it unlikely in most cases that the absence of a statement would give rise to a negative inference. In a rare case where the dying declarant makes a full statement, failure to identify someone close to her as the killer might be so unusual that an inference would be drawn. In such cases the rule admitting the evidence receives additional support froin the focus on juror expectations.

157. See generally Payne, The Hillmon Case-An Old Problem Revisited, 41 VA. L. Rev. 1011 (1955).

158. See, e.g., FED. R. Evid. 803(1).

159. See, eg., FED. R. Evid. 803(2).

160. See, e.g., FED. R. Evid. 803(6).

161. See, e.g., FED. R. Evid. 803 \& 804.

162. See Note, Did Your Eyes Deceive You? Expert Psychological Testimony on the Unreliability of Eyewitness Identification, 29 STAN. L. REv. 969, 982 (1977) [hereinafter cited as Note, Expert Psychological Testimony]. 
retrospective statement will be better evidence than one fallimg withm the Hillmon exception. Such a statement should be admissible because it is especially reliable. Some commentators, disregarding the bulk of hearsay exceptions and newer residual exceptions like those found in the Federal Rules of Evidence, ${ }^{163}$ have stramed to find an excuse for admissibility under the state of mind part of the personal condition exception. ${ }^{164}$ Often these commentators have ignored more straightforward solutions, in favor of convoluted refinements of the personal condition rulcs. Shepard itself stands only for the proposition that most situations provide insufficient guarantees of rehability (which is the bottom line of the hearsay rule itself) and that retrospective statements generally should not be admitted. ${ }^{165}$ It does not prevent the creation of a rule covering cases imvolving especially reliable evidence. Similarly, there inay be factual settimgs-for example, where a jury learns that a person participated in a group discussion of an event but is not told what that person said-where the possibility of a negative inference might warrant admission of the evidence even though it is backward looking. ${ }^{166}$

\section{Beyond the Personal Condition Exceptions}

Negative inference analysis now has been used to reexamine the personal condition exceptions to the hearsay rule in light of their practical effect on jury expectations. The previous section has deinonstrated that the exceptions as presently drafted im modern codes often coincide with the exceptions supported by a negative inference argument. In most cases these exceptions should work well. But the case by case analysis advocated by this Article and required by the balancing test provided in rules like Federal Rule of Evidence 403 suggests, however, that evidentiary rules should not be followed so automatically that prejudice or injustice is ignored in any particular case.

The limited scope of this Article should not imply that negative inference analysis is only useful in examining the personal condition

163. See, e.g., FED. R. Evid. 803(24) \& 804(b)(5).

164. See, e.g., Seidelson, supra note 145.

165. Absent special circumstances, when a person speaks of an intention to do something im the future and also describes past activity, only the former statements should be admitted. For a disturbing decision to the contrary, see United States v. Annunziato, 293 F.2d 373 (2d Cir.), cert. denied, 368 U.S. 919 (1961). For a well-reasoned analysis see United States v. Mandel, 437 F. Supp. 262 (D. Md. 1977).

166. It is extremely doubtful whether the residual exceptions to the federal hearsay rule cited in note 163, supra, could be invoked to prevent an unfair negative inference. The criteria for these exceptions focus almost exclusively on the necessity of receiving hearsay and on the reliability of the offered evidence. It is arguable perhaps that recognition of the negative inference would support an argument based on necessity. If so, the proffered evidence might be better than other available evidence. But would the guarantees of trustworthiness be sufficient? That probably would depend on the precise evidence offered. 
exceptions to the hearsay doctrine. The analysis is helpful in understanding and justifying many other hearsay exceptions. For example, statements concerning the creation or amendment of a will, ${ }^{167}$ statements of pedigree, ${ }^{168}$ and business records ${ }^{169}$ are the kind of information a jury is likely to expect to hear in court because of its everyday experience with such matters. The analytic form should now be familiar enough to make any prolonged explanation of the particulars of each exception unnecessary.

Furthermore, since negative inference analysis applies to all evidentiary issues, the analysis may be useful in resolving a variety of close questions concerning the appropriate rule of evidence to govern other repetitive factual patterns. While all possible applications cannot be catalogued, I will discuss two other issues that are currently receiving a great deal of attention.

\section{Impeaching Witnesses with Prior Convictions}

First, I reiterate that there is a developing line of cases ${ }^{170}$ that suggests that Federal Rule of Evidence 609(a)(1) protects only the defendant and probably only in criminal cases. ${ }^{171}$ Rule $609(\mathrm{a})(\mathrm{l})$ provides in relevant part that a witness may be impeached with evidence of a prior

167. See, e.g., FED. R. Evid. 803(3); CAL. Evid. CODE $\$ 1260$ (West 1966). The Advisory Committee on the Federal Rules of Evidence accepted Professor McCormick's reasoning in support of the rule. See 56 F.R.D. 183, 306 (1972).

In wills cases the special need for the hearsay use of the testator's declarations to show

his previous acts is apparent. The testator is dead and is usually the one who best knew

the facts, and is often the only one who had any knowledge of them. The special reliabil-

ity, though it is arguable that he may often want to deceive his relatives, is strongly

supported by his first-hand knowledge and by his lack of selfish interest.

C. MCCoRMICK, supra note $101, \S 271$, at 577 . This argument says hittle more than that some outof-court statements will be good evidence and others will not. A rationale more closely suited to wills cases is that juries can expect that the creation or modification of a will is the kind of solenin, extraordinary task that will cause the testatrix to comment on it to those close to her. In some cases at least, for example when the making or revocation of a will is at issue, the absence of evidence of the maker's declarations will produce unfortunate negative inferences.

168. See, e.g., FED. R. EvID. 804(b)(4), which conditions admission on unavailability. Although the usual arguments for this exception center on necessity or trustworthiness, without the admission of the hearsay evidence a jury may conclude in many situations that major events in a person's or family's life did not take place.

169. See, e.g., FED. R. Evid. 803(6). The business records exception is so easily justified on other grounds that its inclusion here might be surprising. But one aspect of the rule, its acceptance of self-serving business records, fits nicely into the analysis. Jurors will expect routme records to be kept and may draw unfair negative inferences if the records are not introduced. Although records can be excluded if they indicate a lack of trustworthiness, courts should consider possible negative inferences and recognize the jurors' ability to weigh the probative value of the evidence before excluding it.

170. See note 9 supra.

171. Everyone apparently agrees that FED. R. EvID. 609(a)(2) apphes to all cases and all sides. 
felony conviction ${ }^{172}$ if "the court determmes that the probative value of admitting this evidence outweighs its prejudicial effect to the defendant." In effect, the cases hold that a criminal defendant's testimony cannot always be impeached by the introduction of a prior record, but the testimony of any other witness can be. Elsewhere I have argued that " $[t]$ o the extent that the opinions suggest that no Federal Rule protects the government, there are three flaws in their reasoning, two minor and one major." 173 But accepting the opimons' interpretation for the purposes of this discussion, negative inference analysis suggests that the rule should be changed.

Three hypothetical cases will focus the mquiry. In one, the defendant is charged with rape and the victim is a key government witness. In the second, an accomphice is a most important government witness. In the third, an innocent bystander is a critical government witness. In all cases, the important government witness has one prior conviction, which comcidentally is the same as the defendant's one previous felony conviction-robbery. ${ }^{174}$

The present application of rule 609(a)(1) prevents the prosecution from introducing the defendant's prior conviction, but would allow the defense to impeach each of the government witnesses. There has been justifiable outrage in recent years concerning the improper use of character evidence to discredit rape victims. Of course, the impeachunent by means of a prior conviction is not as demeaning as an inquiry into

172. I.e., a crime "punishable by death or imprisonment in excess of one year under the law under which he [the witness] was convicted." FED. R. Evid. 609(a)(1).

173. S. SAltzBurg \& K. RedDen, supra note 9, at 331. The argument is as follows:

The minor flaws are undue emphasis on individual rcmarks in the floor debates when the debates reveal that impeachment for bias often was confused with impeachment by a prior conviction, and the equation of prejudice to a witness (not a concern of the Rule) with prejudice to a party (the target of the Rule in our view). More important is the failure to recognize that if Rule 609(a)(1) does not cover use of all convictions and prejudice to all parties, nothing in the Rules exphicitly does. It is true that prejudice to criminal defendants is a unore common problem than prejudice to the government, and this explains the focus of Rule 609 (a)(1) on those accused of crime. But, impeachment has always been a two way street and no good reason appears to allow the government or civil litigants to be unfairly prejudiced. Hence, Rule 403 presumably would apply and the result would be approximatcly the same as if Rule 609(a)(1) were read to protect the government as well as defendants. The only difference between an approach under Rule 609(a)(1) and Rule 403 is that the former Rule requires that evidence be more probative than prejudicial to be admitted whereas the latter requires for exclusion that the prejudicial effect substantially outweigh the probative value. In our view the special protection of Rule 609(a)(1) against use of prior convictions-in doubtful cases excluding the evidence-was intended to protect only criminal defendants, whereas the general notion of balancing harmful against helpful attributes of convictions-in doubtful cases admitting the evidence-was intended to reach and to protect all parties against undue prejudice. Whether this result is reached by interpreting Rule 609 (a)(1) in the light of Rules 102 , 403 , and 611 , as we advocate . . . or by relying on one of those Rules independently, as the Smith [551 F.2d 348 (D.C. Cir. 1976)] opinion suggests might be necessary, is a matId. ter of no great inoinent. . .

174. See, e.g., United States v. McMillian, 535 F.2d 1035 (8th Cir. 1976). 
prior sexual conduct. But the case may turn on the credibility of the victim and the accused. Should they be treated unequally? Should there be no outrage when a rape victim's record can be revealed but that of a defendant who testifies cannot be? Does it make sense that im any criminal case an accomplice who might risk physical harm by cooperatimg with the government, or a witness willing to weather the storm of mvolvement in the criminal justice system, can be portrayed as less behevable than a testifying defendant with the same prior record?

A negative inference analysis can help answer these questions. If a jury hears of a key government witness' prior conviction, but not of the defendant's, the jury may well infer that the government witness is suspect while the defendant is not. ${ }^{175}$ The conclusion would be that the defendant, who appears to have an unbleimshed record, is more believable than the witness. The policy of protecting the defendant from prejudice does not require such a one-sided result. It is probably true that a criminal defendant, who stands accused by public authority and is in danger of suffering a substantial penalty, needs more protection than the government, which is viewed somewhat independently of its witnesses. But the policy can be effected by deciding close balancing questions in favor of the defendant; ${ }^{176}$ there is no need to abjure totally the goal of protecting the government as well. And in civil cases, where the negative inference problem can be as great, there is no good reason to favor defendants over plaimtiffs. Each case should be decided on its particular facts by balancing the actual imterests at stake, rather than by automatically applying federal rule 609(a)(1) to favor one party over another regardless of the facts.

\section{Challenging the Reliability of Eyewitness Testimony}

Second, a question has been raised whether the probability "[t]hat most juries, and even some judges, are unaware of the sources of error in eyewitness testinnony and consequently place undue faith in its veracity" 177 requires courts to see to it that "some steps are taken to ensure that the unrehiability of eyewitness evidence is brought to the attention of the trier of fact." 178 At the moment few courts admit such

175. It is true that a jury might take into account the defendant's interest in testifying, but the same type of interest is taken into account when an accounplice turns state's evidence. Moreover, other witnesses inay be impeached for bias, interest, or for inconsistent statements, so it is not so easy to assume that the defendant is so uniquely suspect in the jurors' eyes that prior convictions always amount to overkill. $C f$. United States v. Jackson, 405 F. Supp. 938 (E.D.N.Y. 1975). See also Lowell v. State, 575 P.2d 1281 (Alaska 1978); Godwin v. State, 38 Md. App. 611, 379 A.2d 754 (1977).

176. See note 173 supra.

177. Note, Expert Psychological Testimony, supra note 162, at 970 (footnote onitted).

178. Id. at 970-71. 
evidence, ${ }^{179}$ although its use inay be on the increase. ${ }^{180}$ In most jurisdictions no rule ${ }^{181}$ bars the introduction of the evidence; the decision to admit or to exclude is left to the trial judge, who traditionally has excluded on the ground that the evidence is more prejudicial than probative. $^{182}$

Is it true that "most jurors probably operate under the assumption that eyewitness testimony presumptively is accurate'? ${ }^{183}$ Only empirical research possibly could justify a definite answer, and it remains to be done. Supporting an affirmative but less definite answer based on logic is the realization that the adversary system is largely based on exposure of weaknesses in witnesses, testimony, and physical evidence through cross-examination, impeachment, and counter-evidence. Evidence not attacked is evidence readily accepted. If the only effective attack on eyewitness evidence is expert testimony, the absence of such testimony may cause judges and jurors too quickly to accept the evidence.

The negative inference problem attributable to the introduction of some evidence coinbined with the absence of critical testimony is a real one. It has led one thoughtful commentator to recommend admission of expert evidence regarding eyewitness identification. ${ }^{184} \mathrm{~A}$ rule requiring admission of the evidence could be adopted. But this suggestion ignores yet another problein of juror expectations. Jurors, or even judges, who hear an expert on eyewitness evidence testify in one case but not another, might erroneously conclude that the absence of the evidence is tantamount to tacit acceptance of an eyewitness' testimony, ${ }^{185}$ when it may be that the defense lawyer is not knowledgeable about the evidence, that the defendant caimot afford an expert, that no expert was available to testify, or that the expert retained by the defense is a poor witness. Moreover, the government would wish to respond to a defendant's expert evidence about the defects of eyewitness evidence with its own expert evidence concerning situations in which

179. See, e.g., United States v. Brown, 540 F.2d 1048 (10th Cir. 1976), cert. denied, 429 U.S. 1100 (1977); United States v. Amaral, 488 F.2d 1148 (9th Cir. 1973).

180. See Note, Expert Psychological Testimony, supra note 162, at 1006 n.173.

181. Some jurisdictions might hold that introduction of the evidence usurps the function of the jury. But if the jury is not otherwise fully informed of the dangers of misidentification, the expert who fills gaps in its knowledge and leaves the final determmation to the jury in no way usurps its decisionmaking function. But see the cases cited in id. at 1018-19 \& nn.229-30. See also United States v. Sellers, 566 F.2d 884 (4th Cir. 1977) (error to allow government expert on identifcation to testify and to reject defendant's expert).

182. See, e.g., the four-pronged balancing test of United States v. Amaral, 488 F.2d 1148, 1153 (9th Cir. 1973).

183. Note, Expert Psychological Testimony, supra note 162, at 1017.

184. See id. at 1029.

185. $C f$. R. LEMPERT \& S. SALTZBURG, supra note 8, at 1020 (nuunbered paragraph 6); State v. Titns, 358 So.2d 912 (La. 1978) (upholding adinission of evidence that defendant, who elicited evidence of coconspirator's polygraph test results, hinıself refused a polygraph test). 
particular eyewitness evidence is most likely to be accurate. This certainly would be appropriate since the issue in any individual case is how rehiable the eyewitnesses are in the context of that case. But the necessary studies may not have been done yet. If not, the question becomes whether the introduction of expert evidence concerning defects in eyewitness evidence is unfairly one-sided. The more the governinent focuses on strengths of particular eyewitness evidence, the more it may want to rely on expert evidence about individual victims, situations, and witnesses to rebut the inference that its witnesses are suspect. Psychological examinations, even psychiatric studies, could be requested so that the government can meet the defense evidence. If the government offers evidence suggestimg that eyewitness identification is especially rehable in particular cases, it nay be that defendants will request these examinations of witnesses. The societal costs may include an invasion of privacy and the loss of dignity for those citizens who are unwillingly and unhappily brought into the criminal justice system. Ultimately, those persons may not come forward as witnesses, and the societal costs in decreased law enforcement might become considerable.

In sum, jurors who receive no expert information about eyewitness evidence may tend to overestimate its value because they infer that problems that exist would be raised by a defendant. Once such evidence is generally admitted, however, its absence in any case may result in disappointed juror expectations and negative inferences. Moreover, if experts are allowed to testify about general characteristics of eyewitness identification, litigants, seeking to avoid application of the general information to their particular case, may claim new rights to examine witnesses. Thus, competing negative inferences and their implications must be balanced. For too long the problems with eyewitness identification have been ignored. ${ }^{186}$ But a rule requiring admission of expert evidence would present new problems that may be more serious than those it attempts to solve. Ultimately, a better solution may be a carefully drawn standard jury instruction ${ }^{187}$ that can be modified from time to time as new information about eyewitness evidence is generated, or even the presentation of a "n1odel" examination of several eyewitness experts preserved on videotape and approved by the

186. Some have concluded that, as a result, innocent people have been convicted. See the authorities collected in Note, Expert Psychological Testimony, supra note 162, at 969 n.1.

187. One criticism of jury instructions has been that "[i]nstructions alone cannot supply the jury with any data or information that would assist them [sic] in evaluating the reliability of a particular witness' identification." Id. at 1004. But this comment focuses on a particular instruction, that required by United States v. Telfaire, 469 F.2d 552 (D.C. Cir. 1972). There is no reason why data could not be incorporated in jury instructions. Indeed, courts now take judicial notice of "legislative facts." See S. SaltzBurg \& K. RedDEN, supra note 9, at 59-61. Such facts easily could be conveyed to the jury. 
highest court in a jurisdiction. ${ }^{188}$ The best solution of all might be to design carefully controlled pretrial identification procedures. A final answer on how to strike the balance is beyond the scope of this Article, however. For now, it is sufficient to note the problem.

\section{CONCLUSION}

When certain issues are raised in hitigation or particular kinds of evidence are presented, triers of fact, especially juries, often develop expectations about the proof that thereafter will be offered. ${ }^{189} \mathrm{~A}$ party's failure to satisfy those expectations may result in negative inferences, often unfair ones, being drawn against that party. Judges who are capable of divining relevance and balancing probative value against prejudicial effects are capable, if they try, of anticipating juror expectations and possible negative inferences. Consideration of these expectations is desirable in making ad hoc rulings, in formulatimg evidence rules, and in giving jury instructions. Although negative imferences were probably not explicitly taken into account when certain well-established rules were adopted, by focusing on juror anticipation and possible responses to it, one is better able to understand these wellestablished rules. And as new evidentiary problems arise, a negative inference analysis can help reveal hidden problems and suggest otherwise elusive solutions.

188. Such a procedure would have obvious advantages: e.g., the jury would treat the videotape like all other evidence in the case, the jury would understand where the data came from, all hitigants would have access to the tape, and the imprimatur of the highest court would be substantial assurance against reversible error. Like a model instruction, the videotape could be modified froun time to time.

189. One collateral benefit of using a negative inference analysis to admit evidence that might otherwise be excluded is that jurors might finish their service with a better feeling about the legal system. If juror expectations are satisfied whenever it is possible to do so without jeopardizing fair trials, juror frustration might be reduced. 